Historic, Archive Document

Do not assume content reflects current scientific knowledge, policies, or practices. 



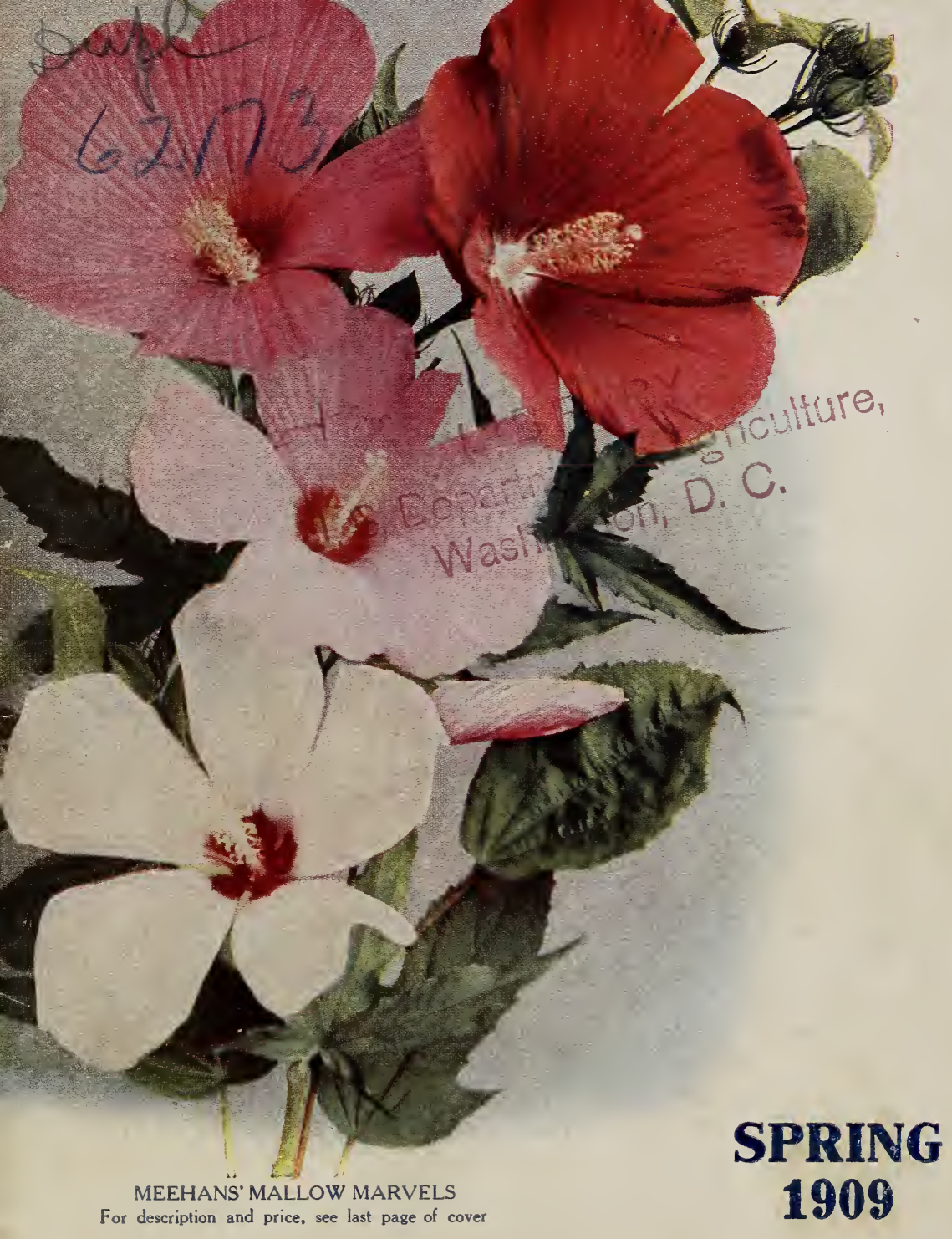

Wholesale Catalogue

Thomas Meehan \& Sons, Inc.

$$
\frac{\frac{\text { WHOLESALE }}{\text { NURSERYMEN }}}{275 \text { ACRES }}
$$

DRESHER, Montgomery County, PENNSYLVANIA 


\section{TRADE LIST}

\section{Spring, 1909}

$\mathbf{I}^{\mathrm{N}}$

$\mathrm{N}$ preparing this, our Trade List for Spring, I909, we have aimed to present our large collection of Hardy Ornamentals to the purchaser in the most concise form. With this object in mind and in view of the fact that it is intended for the trade, illustrations and descriptions have been purposely omitted.

Customers are requested to state the mode of conveyance by which they desire their trees forwarded. When no route is named we forward to the best of our judgment.

Responsibility -After goods are placed on board cars here we assume no responsibility for their safe or prompt delivery, or any injury caused by delay in delivery by the transportation company.

\section{All Claims MUST BE MADE UPON RECEIPT OF GOODS.}

Terms Cash, on or before delivery to express or railroad agents, unless by special arrangement.

Two hundred and fifty, twenty-five or five of any one variety will be furnished at the thousand, hundred and ten rates, respectively, but single plants of one or more varieties will not be sold at less than I5 cents each, except Vines and Herbaceous Plants, the minimum price of which will be Io cents each.

Packing Charged Extra, but only sufficient to cover cost of time and material consumed in the work.

Post Office Orders payable at Dresher P. O., Montgomery Co., Pa. Postal Telegraph Office, Dresher, $\mathrm{Pa}$.

Visitors are always welcome and should take train at the Reading Terminal, 12th and Market Streets, Philadelphia, for Camp Hill Station, or at Broad Street Station, Pennsylvania R. R., for Fort Hill Station. Be sure that the train you take stops at these stations.

Notice.-It is necessary that you should Telephone us (Bell Phone, 226 Ambler; Keystone Phone, 652-Y), in advance of your coming, so that we can send a carriage to the station for you. Our office is $2 \frac{1}{2}$ miles from either station.

\section{THE COMMONWEALTH OF PENNSYLVANIA}

\section{DEPARTMENT OF AGRICULTURE}

\section{Certificate of Inspection of Nursery Stock No. 1303.}

This is to certify that the stock in the nursery of THOMAS MEEHAN \& Sons, INC., of Dresher, County of Montgomery, State of Pennsylvania, was duly examined in compliance with the provisions of the Act of Legislature of Pennsylvania, approved the 3 Ist day of March, A. D., I905, and it was found to be apparently free from San Jose Scale and other dangerously injurious insect pest or pests.

This Certificate expires August 3I, Ig09.

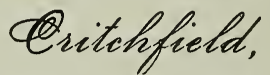




\section{Deciduous Trees}

The price of nursery stock is fixed according to the value of the tree offered. The value of the tree depends entirely upon the character of the stock and it is this "value" which makes prices differ in the catalogues of nurserymen. Stock that is sold at a low price is grown with the least posslble expense put upon it, but at a sacrifice to the "quallty." Stock that is thoroughly cultivated, grown in good soll, well manured and several times transplanted cannot be grown cheaply, but its "value" to the planter is increased, and in the long run such stock is cheaper than poorly grown stock at a "low price."

We bring up-to-date methods into the production of our goods. Our soil Is especially adapted for the growing of good nursery stock. We spend thousands of dollars yearly in manures and in cultivating; besides this our trees are frequently transplanted. We cull out and burn all crooked and imperfect trees so that our customers receive full value for the prices charged.

Intending purchasers of nursery stock should keep this in mind when comparing our prices with others. A visit to our nurseries wlll convince any one of the statement we make.

We call particular attention of customers to the trees marked "Specimens." These are trees that have been frequently transplanted, set wide apart in nursery rows and are well developed In every way.

Acer campestre, English Cork Maple

Per 10 Per 100 Per 1000

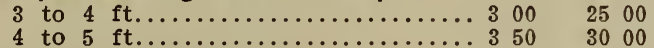

" colchicum rubrum

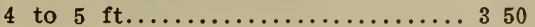

" dasycarpum, Silver Maple

$11 / 2$ to $1 \frac{1}{4}$ in. calliper.......... $500 \quad 4000$

$13 / 4$ to 2 in. calliper.................. 50 ' 6000

2 to $2 \frac{1}{2}$ in calliper................ 90

"dasycarpum Weirii, Weir's Cut-leaf Maple

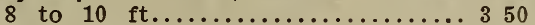

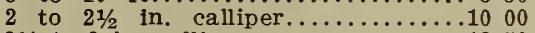

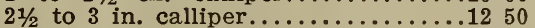

3 to $3 \frac{1}{2}$ in calliper............... 00

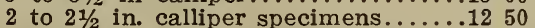

$2 \frac{1}{2}$ to 3 in. calliper, specimens.....15 00

3 to $3 \frac{1}{2}$ in. calliper, specimens.....20 00

$3 \frac{1 / 2}{}$ to 4 in. calliper, specimens.....25 00

4 to 5 in. calliper, specimens..........32 50

" negundo, Ash-leaved Maple, Box Elder

$11 / 2$ to 2 in. calliper............... 350

$21 / 2$ to 3 in. calliper................ 850

3 to 4 in. calliper............... 50

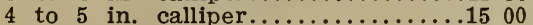

“Pennsylvanicum (striatum), Striped Maple

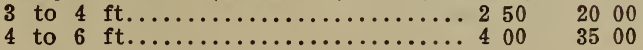

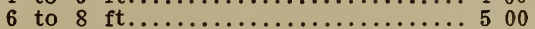


Acer polymorphum, Green-leaved

Per 10 P'er 100 Per 1000

12 to 18 in. 5 in. pots............ 500

2 to $21 / 2$ ft. field grown.............. 750

2 to $3 \mathrm{ft} .6$ in. pots ...........12 50

“ polymorphum ampelopsilobum

2 to $2 \frac{1}{2} \mathrm{ft}$. field grown..........12 50

$21 / 2$ to 3 ft. 6 in. pots.............. 1500

3 to $31 / 2 \mathrm{ft}$. field grown.............. 50

" polymorphum atropurpureum, Blood-leaved

18 to 24 in. field grown........750

18 to 24 in. 6 in. pots.......... 50

2 to $2 \frac{1}{2} \mathrm{ft}$. field grown............... 50

$21 / 2$ to $3 \mathrm{ft}$. field grown..........25 00

3 to $31 / 2 \mathrm{ft}$. field grown, specimens...40 00

polymorphum cristatum, Green Fern-leaved

18 to 24 in. field grown........... 00

18 to 24 in. 6 in. pots................. 50

" polymorphum dissectum, Green Cut-leaved

2 to $21 / 2 \mathrm{ft}$. field grown........12 50

$2 \frac{1}{2}$ to $3 \mathrm{ft.} 6$ in. pots................. 50

. polymorphum dissectum atropurpureum, Purple Cutleaved

18 to 24 in. 6 in. pots............12 50

2 to $3 \mathrm{ft}$. field grown............. 50

3 to $4 \mathrm{ft}$. field grown...........25 00

3 to $4 \mathrm{ft} .6$ in. pots.............20 00

" polymorphum pinnatifolium, Green-leaved

$2 \mathrm{ft} .6$ in. pots.................. 00

" polymorphum reticulatum

2 to $2 \frac{1}{2} \mathrm{ft}$. field grown............ 50

2 to $2 \frac{1}{2} \mathrm{ft} .6$ in. pots............... 00

“ polymorphum sanguineum, Purple-leaved

12 to 18 in. 5 in. pots............ 00

18 to 24 in. field grown..........6 600

18 to 24 in. 5 in. pots............6 50

2 to $2 \frac{1}{2} \mathrm{ft} .5$ in. pots............... 750

Aesculus hippocastaneum, Eu. Horse Chestnut

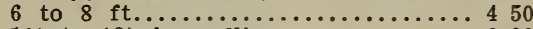

$11 / 2$ to $1 \frac{134}{4}$ in. calliper.................. 600

$13 / 4$ to 2 in. calliper.............. 00

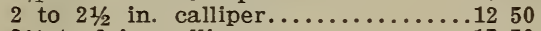

$21 / 2$ to 3 in. calliper................ 50

3 to $3 \frac{1}{2}$ in. calliper................20 00

" hippocastaneum alba plena, Double White Flowered

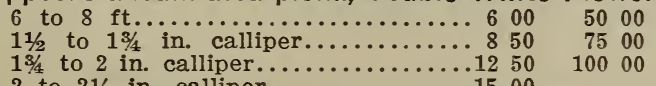

2 to $2 \frac{1}{2}$ in. calliper............... 1500

“ hippocastaneum rubra plena, Double Red

6 to $8 \mathrm{ft}$. 2 year heads.............. 1000

8 to $10 \mathrm{ft}$. 2 year heads.............15 00

Ailanthus glandulosa, female, Tree of Heaven

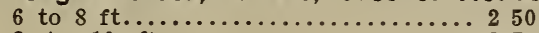

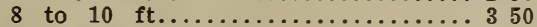

Alnus serrulata (rugosa)

4 to $5 \mathrm{ft}$. heavy specimens........ 350

Amygdalus Persica, Double Pink Flowering Peach 3 to 4 ft.................... 150

" Persica, Double White Flowering Peach

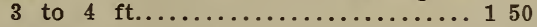

" Perslca Double Red Flowering Peach

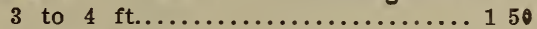

Aralia Japonica

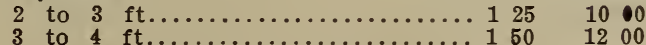


Aralia Mandshurica (Dimorpanthus)

Per 10 Per 100 Per 1000

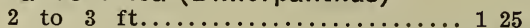

“ spinosa

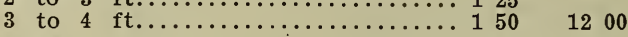

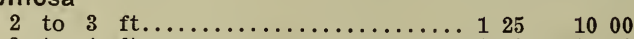

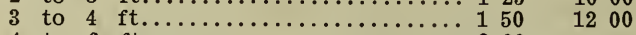

Betula alba, Eu. White Birch

2 to 3 ft.................... $125 \quad 1000$

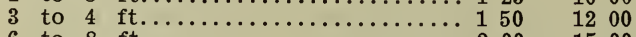

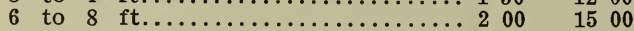

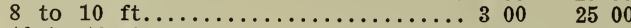

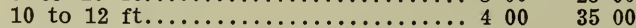

20000

30000

" alba laciniata, Cut-leaf Weeping Birch

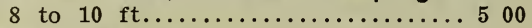

"lenta, Sweet Birch

3 to 4 ft................... 200

4 to 5 ft............................ 300

5 to 6 ft...................... 350

“ lutea, Yellow Birch

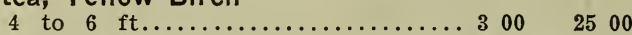

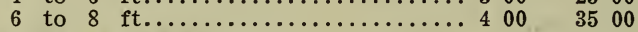

" papyracea, Paper Birch

6 to 8 ft.................. $450 \quad 4000$

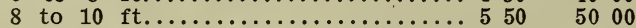

" populifolia, Poplar Birch

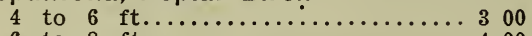

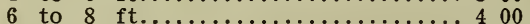

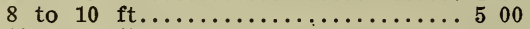

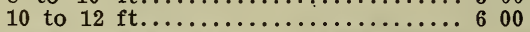

“ rubra (nigra), Red or Water Birch

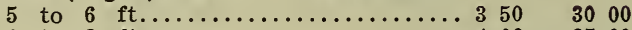

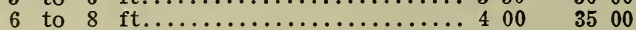

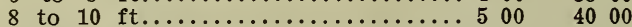

25000

Our Birches are all bushy trees branched to the ground.

Caragana arborescens (see Shrubs)

Caragana arborescens pendula

4 to $5 \mathrm{ft}$. 3 year heads.......... 850

6 to $8 \mathrm{ft} .3$ year heads.............. 1000

Carpinus Americana, Am. Hornbeam or Water Beech

12 to 18 in.................... $50 \quad 400$

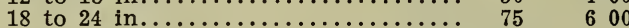

3500

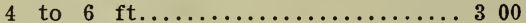

8 to $10 \mathrm{ft} . \ldots \ldots \ldots \ldots \ldots \ldots \ldots \ldots \ldots \ldots, 400$

“ Betulus, European Hornbeam

18 to 24 in. bushy.............. $85 \quad 600 \quad 5000$

These European and the small sizes of American Hornbeam have been grown especially for hedge planting.

\section{Carya amara}

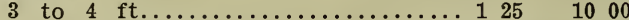

4 to 5 ft............................. $00 \quad 1800$

" olivaeformis, Pecan

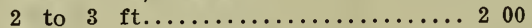

" sulcata, Western Shellbark

2 to 3 ft.................... 125

Castanea Americana, Sweet Chestnut

6 to $8 \mathrm{ft} . \ldots \ldots \ldots \ldots \ldots \ldots \ldots \ldots \ldots, \ldots \ldots$

Catalpa Bungeii, Standard

2 year heads.................. 500

“ Bungeii nana, Dwarf Catalpa

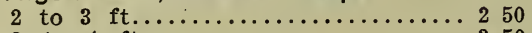

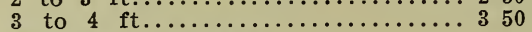

"Kaempferi, Japanese

4 to 5 ft................. $250 \quad 2000$ 
Catalpa speciosa, Western Catalpa

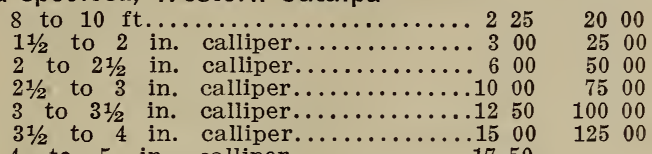

Cedrelia sinensis

to 5 in. calliper...............

2 to $21 / 2$ in. calliper, specimens......12 50

$21 / 2$ to 3 in. calliper, specimens......15 00

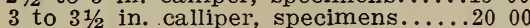

$31 / 2$ to 4 in. calliper, specimens....25 00

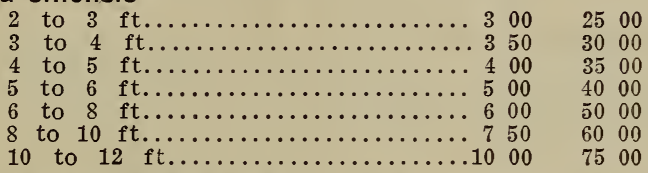

The Cedrelia sinensis is a tree similar in appearance and general character and habit to the Ailanthus, and will thrive under similar conditions, but it does not have the disagreeable odor when in flower. It is without doubt one of the best trees for street planting in cities and will thrive where no other tree will grow.

Cerasus sinensis ranunculaeflora, Double White Flowering Cherry

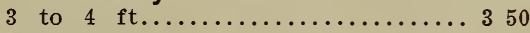

“ Sieboldi rubra plena, Double Pink

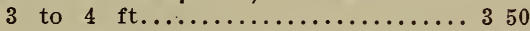

- Japonica rosea pendula, Weeping Rose FI. Cherry

6 to $8 \mathrm{ft}$. stem, 3 year head........ 750

"Padus

2 to $3 \mathrm{ft} . \ldots \ldots \ldots \ldots \ldots \ldots \ldots \ldots \ldots \ldots$

Cercis Canadensis and Japonica, see shrubs

Cercidiphyllum Japonicum

6 to $8 \mathrm{ft} . \ldots \ldots \ldots \ldots \ldots \ldots \ldots \ldots \ldots \ldots \ldots$

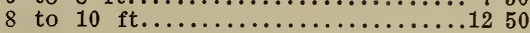

Cladrastis tinctoria (Virgilia lutea), Yellow Wood

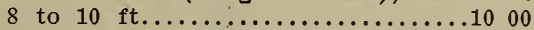

Cornus florida, White Flowered Dogwood

2 to 3 ft...................... $175 \quad 1500 \quad 12500$

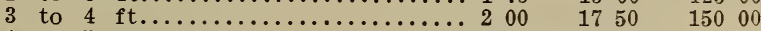

4 to 5 ft........................ $250 \quad 2000$

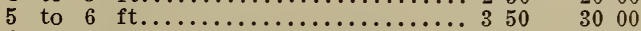

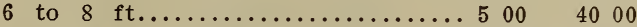

florida pendula, Weeping White Flowered Dogwood

2 to $3 \mathrm{ft} . \ldots \ldots \ldots \ldots \ldots \ldots \ldots \ldots \ldots \ldots \ldots$

“ florida rubra, Red Flowered Dogwood

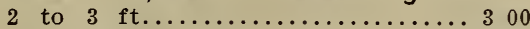

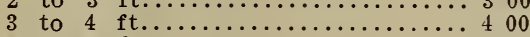

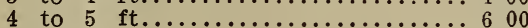

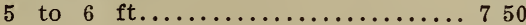

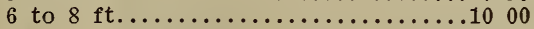

2500

3500

5000

6500

8500

"Other varieties (see Shrubs)

Crataegus (See Shrubs

Dimorpanthus Mandschurica (see Aralia Mandschurica)

Dlospyrus Virginiana. American Persimmon

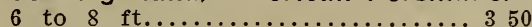

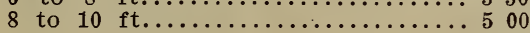

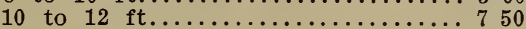

$40 \quad 00$

6000 
Fagus sylvatica, European Beech

Per 10 P'er 100 Per 1000 12 to
2 to
3 to
4 to
5 to

4

heterophylla, Cut-leaved Beech

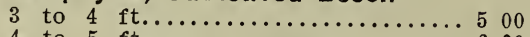

4 to 5 ft........................

" pendula, Weeping Beech

2 to 3 ft................... 400

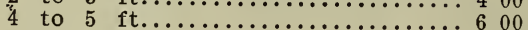

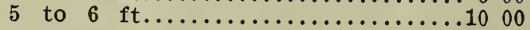

" purpurea, Copper Beech

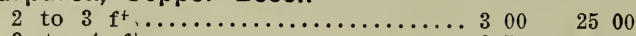

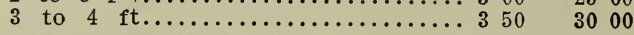

"Rivers' Blood-leaf Beech

3 to $4 \mathrm{ft} . \ldots \ldots \ldots \ldots \ldots \ldots \ldots \ldots \ldots, 400$

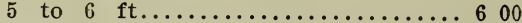

6 to 8 ft............................. 00

" purpurea pendula, Weeping Blood-leaf Beech

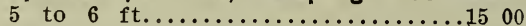

Fraxinus Americana, American White Ash

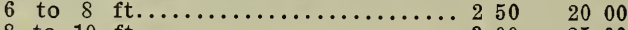

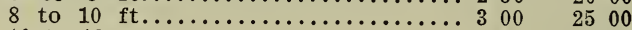

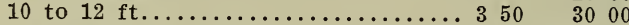

$11 / 2$ to 2 in. calliper.............. 5 $00 \quad 4000$

2 to $2 \frac{1}{2}$ in. calliper...........6 600

$600 \quad 5000$

$\begin{array}{ll}18 & 00 \\ 25 & 00\end{array}$

4000

5000

xcelsior. English Ash

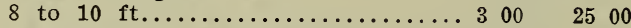

Fraxinus Ornus, Flowering Ash

8 to $10 \mathrm{ft} . \ldots \ldots \ldots \ldots \ldots \ldots \ldots \ldots \ldots, 400$

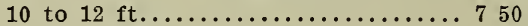

"quadrangulata, Blue Ash

6 to 8 ft........................ $300 \quad 2500$

$11 / 2$ to 2 in. calliper............... $500 \quad 4000$

2 to $21 / 2$ in. calliper................. 750

$21 / 2$ to 3 in. calliper.................

- $1 \frac{1}{2}$ to 2 in. calliper, specimens..... 750

2 to $2 \frac{1}{2}$ in. calliper, specimens.......10 00

" sambucifolia, Black Ash

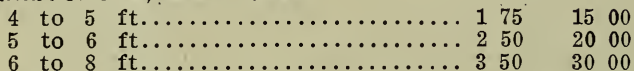

This is the variety known in the vicinity of Chicago as the "Bronze Ash."

" viridis, Green Ash

$11 / 2$ to 2 in. calliper............4 400

Gleditschia triacanthos, Honey Locust

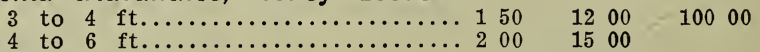

" inermis, Thornless

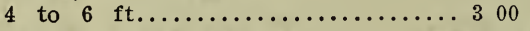

Gymnocladus canadensis, Kentucky Coffee Tree

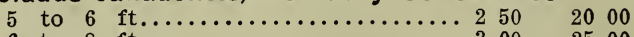

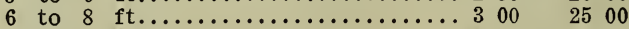

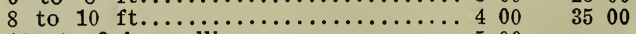

$11 / 2$ to 2 in. calliper................. 00

2 to $2 \frac{1}{2}$ in. calliper...............6 600

Juglans cineria, Butternut

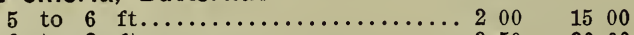

6 to 8 ft....................... $350 \quad 3000$

" nigra, Black Walnut

18 to 24 in................... $125 \quad 1000$

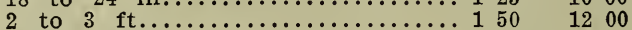

3 to 4 ft......................... $00 \quad 1500$ 
Juglans regia, English Walnut, Madera Nut

Per 10 Fier 100 Per 1000

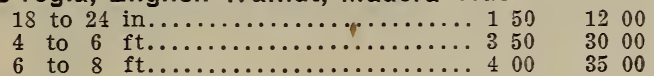

Larix Europaea, European Larch

2 to 3 ft.................... 150

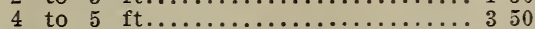

Liquidambar styraciflua, Sweet Gum
3 to 4 ft..................... 250

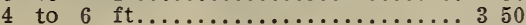
2000
6 to 8 ft...........................
3000
6000

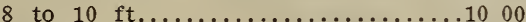

Liquidambar grown from seeds or seedlings produced in the south are not hardy as far north as Philadelphia. There are a few native trees in Eastern Pennsylvania. We gather seed from these trees and grow our own seedlings, and as a result our trees are hardy much farther north and west.

Liriodendron tulipifera, Tulip Tręe

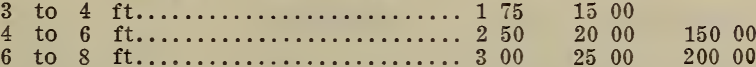

Magnolia Acuminata

3 to 4 ft.................... 200

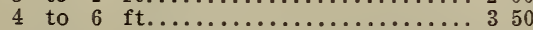

"Kobus

3 to 4 ft.................. 500

4 to 5 ft..................... 550

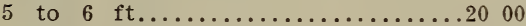

6 to $8 \mathrm{ft}$. specimens.............25 00

MAGNOLIAS

Large Flowered Chinese Varieties

“ Alexandrina

3 to $4 \mathrm{ft}$. with ball.............. 00

4 to $5 \mathrm{ft}$. with ball.................... 50

" conspicua, Chinese White Magnolia

2 to $3 \mathrm{ft}$. with ball.............. \& $50 \quad 7500$

3 to $4 \mathrm{ft}$. with ball................. $1000 \quad 9000$

4 to $5 \mathrm{ft}$. with ball..................... $50 \quad 10000$

5 to $6 \mathrm{ft}$ with ball............... $00 \quad 13500$

6 to $8 \mathrm{ft}$. with ball.............20 00

" gracilis, Dwarf Purple

2 to $3 \mathrm{ft}$. with ball ............ 850

3 to $4 \mathrm{ft}$. with ball................... 00

“ Lennei, Large Purple Flowered

2 to $3 \mathrm{ft}$. with ball................10 00

3 to $4 \mathrm{ft}$. with ball.............. 1250

" purpurea

18 to 24 in. with ball............6 $600 \quad 5000$

2 to $3 \mathrm{ft}$. with ball............ $850 \quad 7500$

3 to $4 \mathrm{ft}$. with ball................ 00

“ Soulangeana, Large Pink Flowered Magnolla

2 to $3 \mathrm{ft}$. with ball.............. $850 \quad 7500$

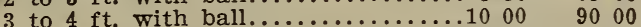

4 to $5 \mathrm{ft}$. with ball................ 50

5 to $6 \mathrm{ft}$. with ball.................... 001500

6 to $7 \mathrm{ft}$. with ball, specimens......17 $50 \quad 15000$

“ speciosa, Early Pink Flowered Magnolia .

2 to $3 \mathrm{ft}$ with ball............. 850

3 to $4 \mathrm{ft}$. with ball............... 1000

4 to $5 \mathrm{ft}$. with ball............... 50

5 to $6 \mathrm{ft}$. with ball.............. 00 
Per 10 P'er 100 Per 1000

Magnolia stellata (Halleana), Hall's White Star Flowered

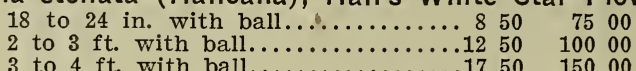

All of the above Magnolias are of our own propagating and grown from layers, and are on their own roots. These are much healthier and better than imported stock; this is especially the case with the Halleana. Each plant will be dug with a ball of earth and the ball sewed in burlap. The conspicua are the true pure white variety.

Morus Tartarica, Russian Mulberry

5 to $6 \mathrm{ft} . \ldots \ldots \ldots \ldots \ldots \ldots \ldots \ldots \ldots 150 . \ldots 1200$

“ Tea's Weeping Mulberry

3 year heads ...................6 60

Negundo aceroides. (See Acer negundo, page 1.)

Nyssa multiflora, Sour Gum

2 to 3 ft..................... 350

Oxydendron arboreum, Sorrel Tree

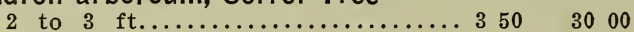

Platanus occidentalis

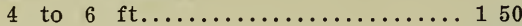

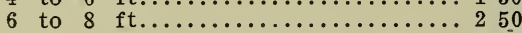

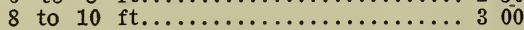

" orientalis, European Sycamore, European Plane

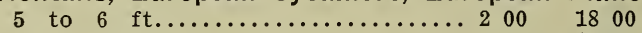

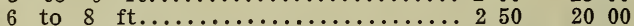

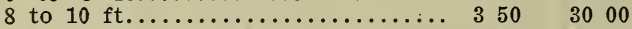

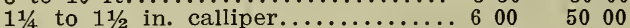

$11 / 2$ to $1 \frac{1}{4}$ in. calliper............10 $00 \quad 9000$

$13 / 4$ to 2 in. calliper............... 50

2 to $2 \frac{1}{2}$ in. calliper.............13 50

12500

Populus alba (argentea), Silver Poplar

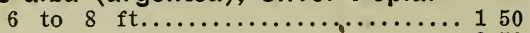

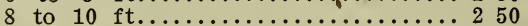

“ Balsamifera, Balsam Poplar

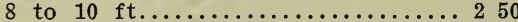

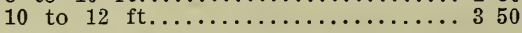

“ Bolleana, Pyramidal Silver Poplar

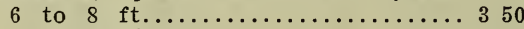

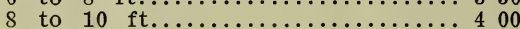

10 to $12 \mathrm{ft} . \ldots \ldots \ldots \ldots \ldots \ldots \ldots \ldots \ldots \ldots$

$13 / 4$ to 2 in. calliper.............6 650

2 to $2 \frac{1}{2}$ in. calliper............ 850

$21 / 2$ to 3 in. calliper............ 1250

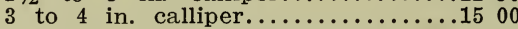

2 to $21 / 2$ in. calliper, specimens.....15 00

$21 / 2$ to 3 in. calliper, specimens.....20 00

3 to $31 / 2$ in. calliper, specimens.....25 00

“ fastigiata, Lombardy Poplar

8 to $10 \mathrm{ft}$. low branched......... 350

10 to $12 \mathrm{ft} .1 \frac{1 / 2}{2}$ to $13 / 4$ in. calliper low

branched ................4 400

3500

4000

7500

10000

15000

25000

2000

3000

3500

“ monilifera, Carolina Poplar

8 to $10 \mathrm{ft} . \ldots \ldots \ldots \ldots \ldots \ldots \ldots \ldots 250$

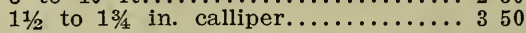

Prunus Pissardi, Purple-leaved Plum

3 to 4 ft..................... 150

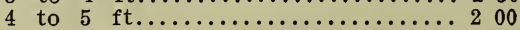

Pyrus aucuparia (see Sorbus aucuparia)

“ Bechtel's Double Flowering (Ionensis)

2 to 3 ft........................ 300

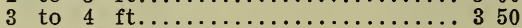

4 to $5 \mathrm{ft}$. heavy............... 1000 
Per 10 P'er 100 Per 1000

Pyrus coronaria, Sweet Scented Crab

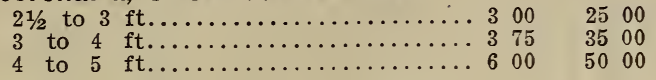

"floribunda

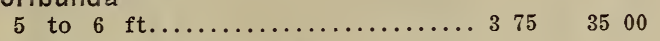

"floribunda atrosanguinea

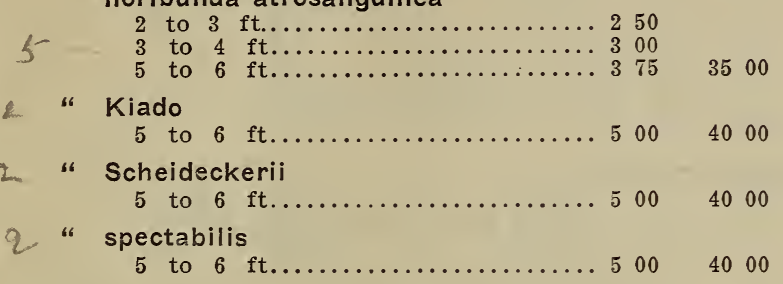

\section{OAKS}

Years ago we began advocating the planting of Oaks for all general purposes; now planters realize their merits. Now they are used for every purpose. They are planted on boulevards, avenues in parks and cemeteries and more recently In the cities. It makes a permanent tree, very free from in. sects and is unsurpassed by any other shade tree. The Pin Oak is particularly adapted for side-walk planting in cities and seems to thrive under the adverse conditions usually found in such places.

Quercus alba, White Oak

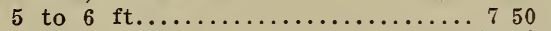

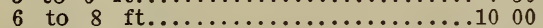

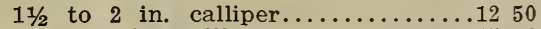

2 to $21 / 2$ in. calliper................ 1500

$2 \frac{1}{2}$ to 3 in. calliper............20 00

" aquatica, Water Oak

4 to $6 \mathrm{ft} . \ldots \ldots \ldots \ldots \ldots \ldots \ldots$............. 00

“ Bannisteri, Scrub Oak

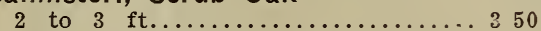

" bicolor, Swamp White Oak

2 to $2 \frac{1}{2}$ in. calliper............... 50

$21 / 2$ to 3 in. calliper.................. 00

3 to $3 \frac{1}{2}$ in. calliper.............25 00

" cerris, Turkey Cak

2 to $2 \frac{1}{2}$ in. calliper............. 1350

$2 \frac{1 / 2}{2}$ to 3 in. calliper...................... 50

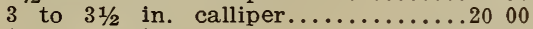

$31 / 2$ to 4 in. calliper.................

4 to 5 in. calliper................... 00

" coccinea, Scarlet Oak

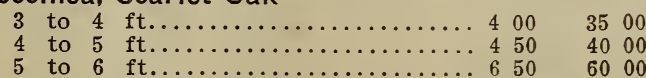

6 to 8 ft. $5 \ldots \ldots \ldots \ldots \ldots$

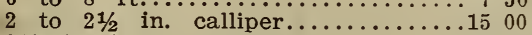

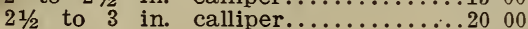

3 to $3 \frac{1}{2}$ in. calliper................25 00

$31 / 2$ to 4 in. calliper.................

" macrocarpa. Mossy Cup or Burr Oak

4 to 6 ft....................... 350

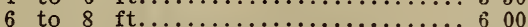

$11 / 2$ to 2 in. calliper................

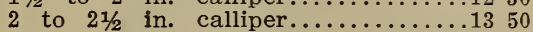

$21 / 2$ to 3 in. calliper...........20 00

6000

8500

10000

3 to $3 \frac{1}{2}$ in. calliper............... 2500 
Quercus palustris, Pin Oak

Per 10 Per 100 Per 1000

4 to 5 ft....................... 350

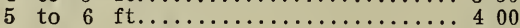

6 to 8 ft....................... 500

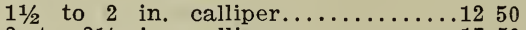

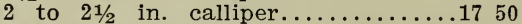

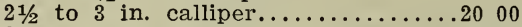

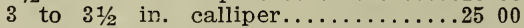

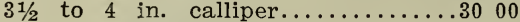

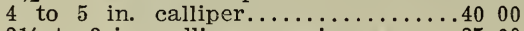

$2 \frac{1}{2}$ to 3 in. calliper, specimens......25 00

3 to $3 \frac{1}{2}$ in. caliiper, specimens.....30 00

$3 \frac{1}{2}$ to 4 in. calliper, specimens......40 00

4 to 5 in. calliper, specimens........50 00

"palustri-imbricaria

$11 / 2$ to 2 in. calliper...........10 00

2 to $2 \frac{1}{2}$ in. calliper.............. 50

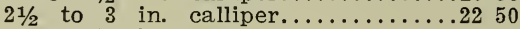

3 to $3 \frac{1}{2}$ in. calliper............30 00

"Phellos, Willow Cak

6 to 8 ft................... 400

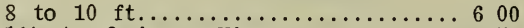

$11 / 2$ to 2 in. calliper............... 750

2 to $2 \frac{1}{2}$ in. calliper............. 1000

$2 \frac{1}{2}$ to 3 in. calliper................. 00

"Prinus, Rock Chestnut Oak

5 to $6 \mathrm{ft} \ldots \ldots \ldots \ldots \ldots \ldots \ldots \ldots \ldots, 400$

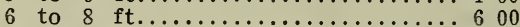

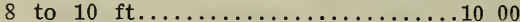

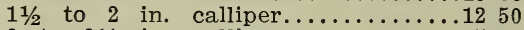

2 to $2 \frac{1}{2}$ in. calliper................. 00

$21 / 2$ to 3 in. calliper.............

"robur, English Oak

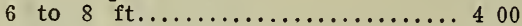

$11 / 2$ to 2 in. calliper................. 1000

2 to $2 \frac{1}{2}$ in. calliper.............. 50

$21 / 2$ to 3 in. calliper................. 00

3 to $3 \frac{1}{2}$ in. calliper............... 50

" rubra, Red Oak

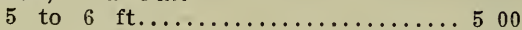

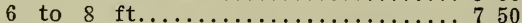

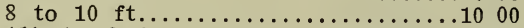

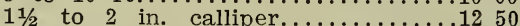

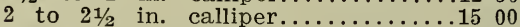

$21 / 2$ to 3 in. calliper.............20 00

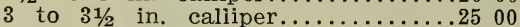

"tinctoria, Black Oak

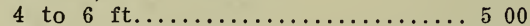

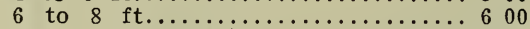

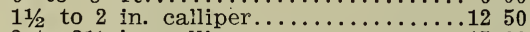

2 to $21 / 2$ in. calliper................. 1500

$21 / 2$ to 3 in. calliper............... 1750

3 to $3 \frac{1}{2}$ in. calliper................... 2000

Robinia pseud-acacia, Yellow or Black Locust

6 to $8 \mathrm{ft} . \ldots \ldots \ldots \ldots \ldots \ldots \ldots \ldots \ldots \ldots \ldots \ldots$

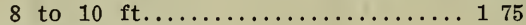

3000

3500

10000

15000

17500

20000

8500

15000

3500

5000

6000

$30 \quad 00$

$50 \quad 00$

8500

10000

12500

60000

75000

$90 \quad 00$

11500

4000

6000

7500

10000

$40 \quad 00$

10000

12500

1000

1200

8000

Salisburia adiantifolia

3 to $4 \mathrm{ft} . \ldots \ldots \ldots \ldots \ldots \ldots \ldots \ldots 200 \quad 1800$

8 to $10 \mathrm{ft}$. $11 / 4$ to $11 / 2$ in. calliper... $600 \quad 5000$

10 to $12 \mathrm{ft}$. $1 \frac{3 / 4}{4}$ to 2 in. calliper... $850 \quad 7500$

Salix aurea pendula

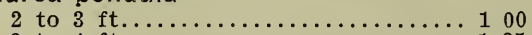

800

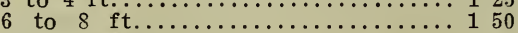

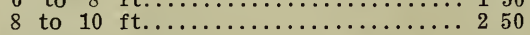

"Babylonica, Babylonian Weeping Willow

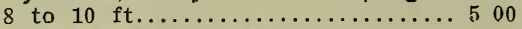

"Britzensis, Red-barked Willow

3 to $4 \mathrm{ft} \ldots \ldots \ldots \ldots \ldots \ldots \ldots \ldots \ldots$ 
Salix petandra, Laurel-leaved Willow

Per 10 Per 100 Per 1000

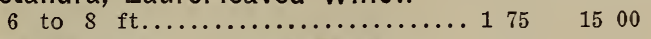

" regalis, Royal or White-leaved

3 to $4 \mathrm{ft} . \ldots \ldots \ldots \ldots \ldots \ldots \ldots \ldots \ldots \ldots$........... $150 \quad 1200$

"Rosmarinifolia, Rosmary Willow

3 to 4 ft..................... 200

" vitellina, Golden Bark

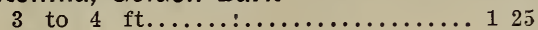

4 to 6 ft. . .

4 to 6 to 8 ft............................

1200

"Wisconsin Weeping

3 to $4 \mathrm{ft} . \ldots \ldots \ldots \ldots \ldots \ldots \ldots \ldots 125 \quad 1000$

Sophora Japonica

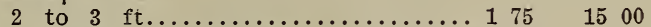

“ Japonica pendula, Weeping Sophora

5 year head.................. 1250

Sorbus aucuparia, European Mountain Ash

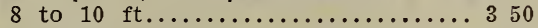

Taxodium distichium, Bald or Deciduous Cypress

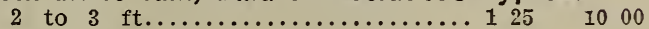

5000

Tilla Americana. American Linden

6 to $8 \mathrm{ft} . \ldots \ldots \ldots \ldots \ldots \ldots \ldots \ldots \ldots 400 \quad 3500$

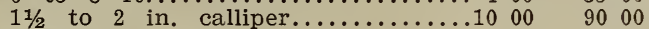

2 to $2 \frac{1}{2}$ in. calliper.............. $1350 \quad 12500$

" alba argentea, Silver-leaved Linden

2 to $21 / 2$ calliper.................15 $00 \quad 13500$

" alba pendula, Weeping Linden

$2-8$ to $10 \mathrm{ft}$. 3 year heads............12 50

10 to $12 \mathrm{ft} .3$ year heads...............

"Europaea, Small-leaved Linden

4 to 5 ft....................... $175 \quad 1500$

“ plataphylla, Large-leaved European Linden

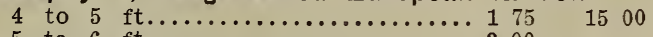

5 to 6 ft........................... 300

Ulmus Americana, American Elm

8 to $10 \mathrm{ft}$., $11 / 4$ to $11 / 2$ in. calliper....5 00

10 to $12 \mathrm{ft}$., $1 \frac{1 / 2}{2}$ to $13 / 4$ in. calliper...6 600

12 to $14 \mathrm{ft}$., $13 / 4$ to 2 in. calliper..... 750

2 to $21 / 2$ in. calliper.................. 1000

$21 / 2$ to 3 in. calliper ................. 1350

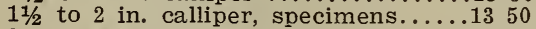

2 to $2 \frac{1}{2}$ in. calliper, specimens......15 00

$21 / 2$ to 3 in. calliper, specimens.....20 00

" Camperdown cendula

5 to $6 \mathrm{ft}$. 2 year heads.......... 500

8 to $10 \mathrm{ft}$. 3 year heads...........12 50

" campestre, English Elm

4 to $5 \mathrm{ft} \ldots \ldots \ldots \ldots \ldots \ldots \ldots \ldots \ldots$

"Huntington

3 to $3 \frac{1}{2}$ in. calliper, specimens....25 00

" latifolia, Scctch Elm

$11 / 2$ to 2 in. calliper............10 00

$21 / 2$ to $2 \frac{1}{4}$ in. calliper.............. 50

15000

These Scotch Elms have perfectly straight trunks and nice tops. They have been several times transplanted.

“ parvifolia, Japanese Elm

4 to 5 ft................... 500

5 to 6 ft................... 50

“ purpurea

$11 / 2$ to 2 in. calliper, specimens......15 00

Virgilia lutea (See Cladrastis tinctoria)

Zanthoxylon Americanum, Prickly Ash

2 to $3 \mathrm{ft} . \ldots \ldots \ldots \ldots \ldots \ldots \ldots \ldots 175$ 


\section{Deciduous Shrubs}

The height of a shrub does not indicate its value to a customer when making comparison in prices. Some nurserymen plant their shrubs thickly in the nursery rows, thereby gaining height, but such shrubs are not bushy. A shrub that is given ample room to develop bushiness will not make the same height in a given time as those which have been planted closely together. We set our shrubs wide apart in the rows and our plants are all good bushy stock; our prices are based on this fact, and customers are given full value for the prices we charge. The shrubs marked "specimens" are large, well developed plants, that have been given ample room in the nursery rows to fully develop, they have been several times transplanted, and they are exceptionally fine shrubs for immediate effect.

Alnus serrulata (rugosa) (see trees)

Amelanchier Botryapium

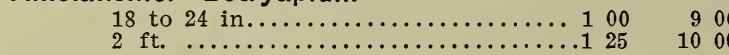

Amorpha canescens

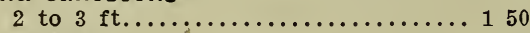

"fruticosa

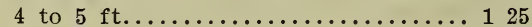

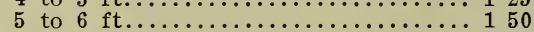

Amygdalus nana, Double White Flowering Almond 2 to 3 ft....................... 150

" nana, Double Pink Flowering Almond

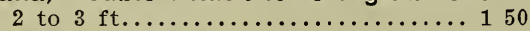

Andromeda calyculata

12 to 18 in.................. 150

* Mariana

12 to 18 in., clumps............ 150

Aralia Japonica

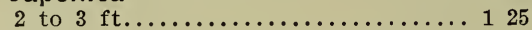

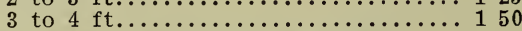

" Mandschurica (Dimorpanthus)

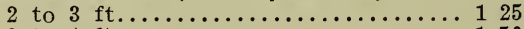

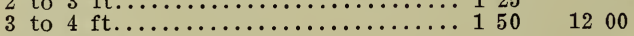

“ pentaphylla

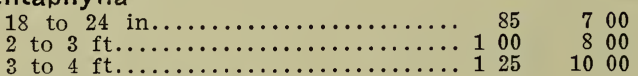

" spinosa

4 to $5 \mathrm{ft}$, specimens............... 200

1000

1200

10

1000

1200

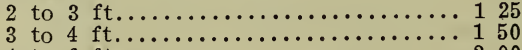

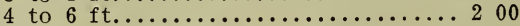

Azalea amoena, Evergreen Azalea

15 to 18 in., 5 -inch pots, very bushy. $400 \quad 3500$

Note that our Azalea amoena are all pot grown plants. They transplant more readily from pots than when dug from the open ground. 
Azalea Mollis, Red

Per 10 Per 100 Per 1000

18 to 24 in....................... 350

2 to $21 / 2$ ft........................ 750

"Mollis, Yellow

18 to 24 in..................... 350

"Pontica (Ghent), assorted colors

18 to 24 in................... $500 \quad 4500$

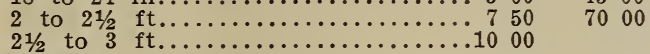

“ viscosa

12 to 18 in....................20 00

Baccharis halimifolia, Groundsel Shrub

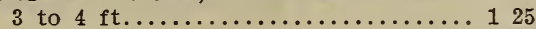

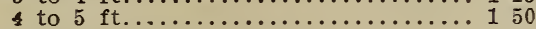

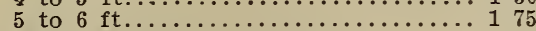

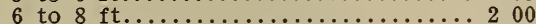

1500

Berberis purpurea, Purple Barberry

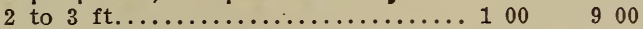

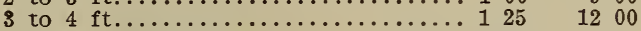

3 to $4 \mathrm{ft} .$, specimens............... 200

"Thunbergii, Japanese Barberry

12 to 18 in ...................... 75

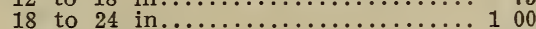

2 to $2 \frac{1}{2}$ ft.................... 125

600

900

5000

" vulgaris, Green Barberry

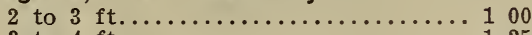

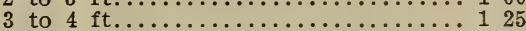

3 to $4 \mathrm{ft} .$, specimens.............. 200

1100

900

1200

Buddleia variabilis

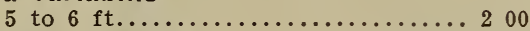

Callicarpa Murisacke

2 to $2 \frac{1}{2}$ ft.................. 150

" purpurea

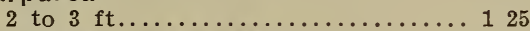

Calycanthus floridus, Sweet Shrub

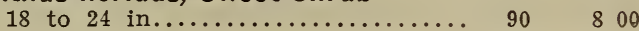

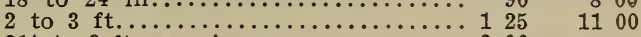

$21 / 2$ to $3 \mathrm{ft}$. specimens.............. 200

Caragana arborescens

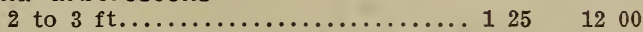

" arborescens pendula, Weeping Siberian Pea

4 to $5 \mathrm{ft}$, 3 year heads............ 850

6 to $8 \mathrm{ft} ., 3$ year heads................ 1000

Carpinus Americana, American Hornbeam (see trees)

"Betulus, European Hornbeam (see trees)

Ceanothus Americanus, New Jersey Tea 18 to 24 in....................... 1251000

Cephalanthus occidentalis, Dwarf Button-bush

18 to 24 in................... $100 \quad 00$

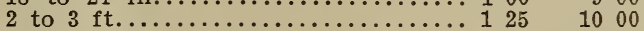

Cercis Canadensis, American Judas or Red Bud

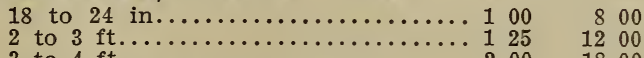

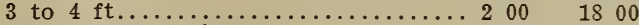

"Japonica, Japanese Judas

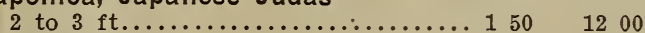

Chionanthus Virginica, White Fringe

18 to 24 in.................... $125 \quad 1000$

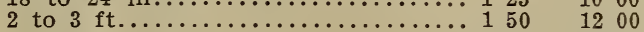

Clethra alnifolia, Sweet Pepper Bush

18 to 24 in................... $90 \quad 800$

Colutea arborescens

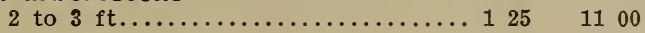


Corchorus, see Kerria

Per 10 Per 100 Per 1000

Cornus alba (Siberica), Red-twigged Dogwood

18 to 24 in ...................... 85

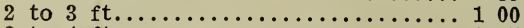

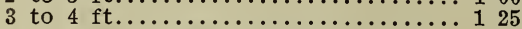

700

900

1100

" alternifolia, Blue Dogwood

18 to 24 in ................... $85 \quad 700$

" circinata

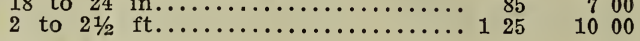

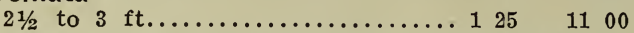

"florida, White Flowered Dogwood (see trees)

“ florida rubra, Red Flowered Dogwood (see trees)

" Mas. Cornelian Cherry

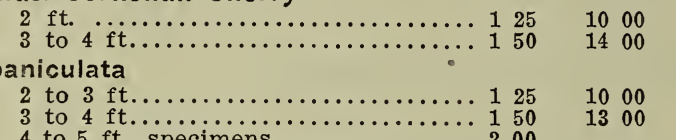

5 to 6 ft., specimens................. 50

os sanguinea, English Dogwood

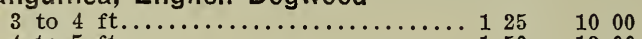

4 to 5 ft...................... $150 \quad 1200$

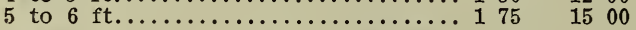

4 sericea (Amomum) Silky Dogwood

18 to 24 in................... $85 \quad 700$

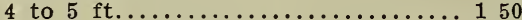

4 to 5 ft., specimens...................

5 to $6 \mathrm{ft}$., specimens............ 250

6 to $7 \mathrm{ft}$., specimens................. 300

" stolonifera lutea (flaviramea), Yellow-barked
18 to 24 in.................. 8500

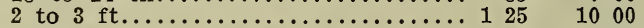

The Cornus sanguinea is the old English Dogwood. Customers desiring the Red-branched Dogwood must order Cornus alba.

Corylus Americana, American Hazel

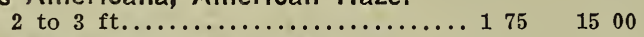

- avellena, European Hazel

2 to $3 \mathrm{ft} . \ldots \ldots \ldots \ldots \ldots \ldots \ldots \ldots . \ldots 1251000$

" purpurea, Purple-leaved Filbert

18 to 24 in..................... $150 \quad 1200$

Cotoneaster Simondsii

2 to $3 \mathrm{ft} . \ldots \ldots \ldots \ldots \ldots \ldots \ldots \ldots \ldots 1251100$

Crataegus coccinea, White Thorn

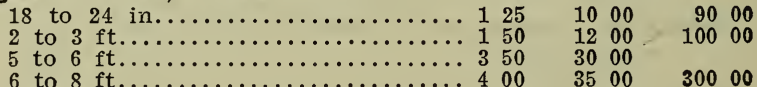

“ Carriere

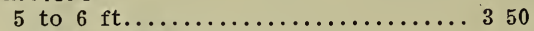

"Cordata, Washington Thorn

18 to 24 in..................... $150 \quad 1200$

2 to 3 ft............................ $75 \quad 1500$

" crus galli, Cockspur Thorn

18 to 24 in.................... $125 \quad 1000 \quad 9000$

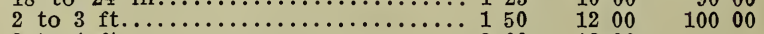

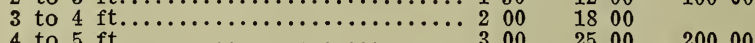

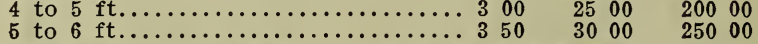

The crus galli, coccinea and oxycantha make excellent hedge plants where a protective hedge is required. The plants should be cut well down to the ground when they are set out, and if this is done they they will make a good bushy hedge the first year. 
Crataegus Mollis

Per 10 Per 100 Per 1000

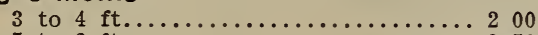

5 to $6 \mathrm{ft} \ldots \ldots \ldots \ldots \ldots \ldots \ldots \ldots \ldots \ldots \ldots, 350$

1800

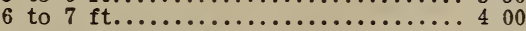

“ oxycantha, English Hawthorn

12 to 18 in..................... 65

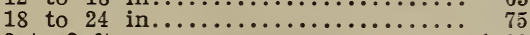

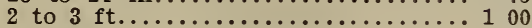

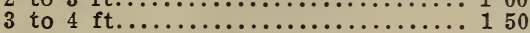

" oxycantha, Double Pink

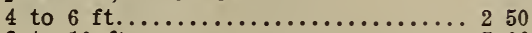

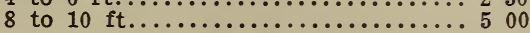

" oxycantha, Faul's Scarlet

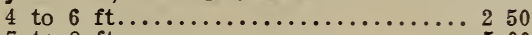

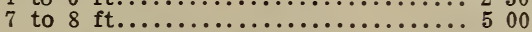

-6 oxycantha, Double White

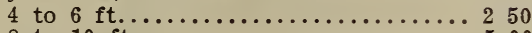

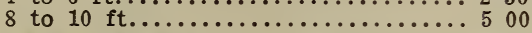

"Pyracantha Lalandi

2 to $3 \mathrm{ft}$., 5 inch pots........... 350

6. spatulata

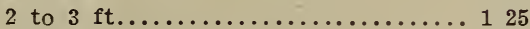

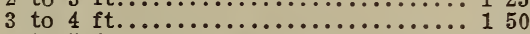

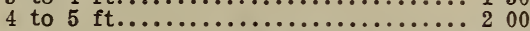

Cydonia Japonica (Pyrus Japonica), Japanese

12 to 18 in...................... 65

18 to 24 in ......................... 75

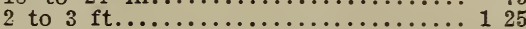

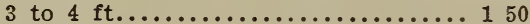

3000

3500

500

600

900

4000

5000

"Maulei, Orange

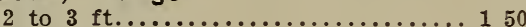

"Moerlossei, Pink

18 to 24 in.................... 125

" umbillicata, bright rose

12 to 18 in.................... 100

Cytissus Laburnum

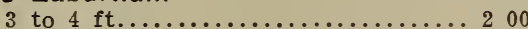

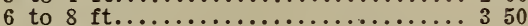

Quince

500

600

1000

5000

1200

1000

$800 \quad 7000$

1800

3000

Daphne Mezereum rubrum

12 to 18 in., 6 inch pots.......... 500

$2 \mathrm{ft.,} 6$ inch pots, bushy........... 750

Desmodium penduliflorum, pin'k

2 year ....................... 150

1200

Deutzia candidissima plena, Double White

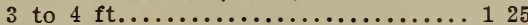

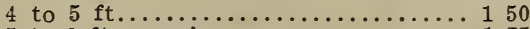

5 to $6 \mathrm{ft}$, specimens................ 175

“

crenata, Double White

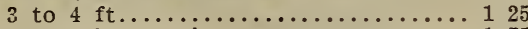

4 to $5 \mathrm{ft}$, specimens................ 175

" crenata, Double Pink

3 to $4 \mathrm{ft}$, bushy................ 125

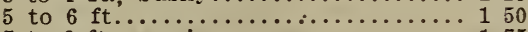

5 to $6 \mathrm{ft}$, specimens................ 175

" gracilis, Dwarf White

12 to 18 in.................. $50 \quad 400$

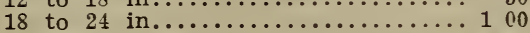

2 to $21 / 2$ ft........................... 125

“ Lemoinei, Dwarf White

18 to 24 in ................... $75 \quad 600$

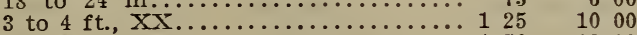

4 to $5 \mathrm{ft} ., \mathrm{XX} . \ldots \ldots \ldots \ldots \ldots \ldots \ldots \ldots 150 \quad 1200$

". Lemoinei compacta, Dwarf White

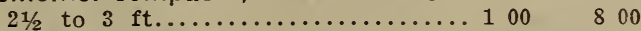

- Pride of Rochester, Double Pink

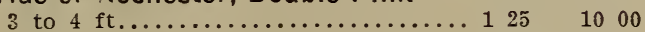


Deutzia scabra, Single White

Per 10 Per 100 Per 1000

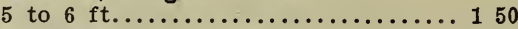

Diervilla Sessilifolia (lutea)

18 to 24 in..................... 125

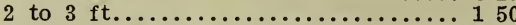

2 to $3 \mathrm{ft}$, specimens................ 200

Dimorpanthus (see Aralia Mandschurica)

Eleagnus longipes

18 to 24 in ........................... 00

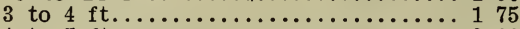

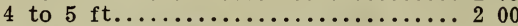

" angustifolia, Russian Olive

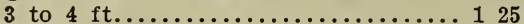

" umbellatus, female

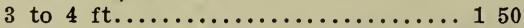

Euonymus Europaeus, European Burning Bush 2 to $3 \mathrm{ft} . \ldots \ldots \ldots \ldots \ldots \ldots \ldots \ldots$

1000

atus, Japanese Euonymus

15 to 18 in ..................... 250

2 to $2 \frac{1}{2}$ ft.............................. 50

" atropurpureus

18 to 24 in..................... $125 \quad 1000$

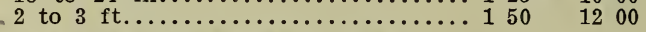

Exochordia grandiflora, Pearl Bush

18 to 24 in..................... $125 \quad 1000$

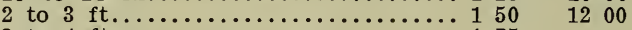

Forsythea Fortunei, Golden Bell

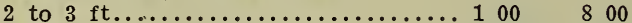

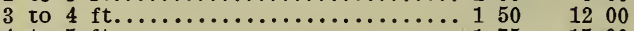

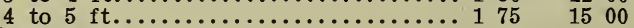

" intermedia

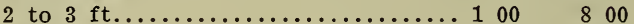

" suspensa

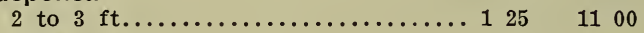

" viridissima

18 to 24 in.................... $75 \quad 600$

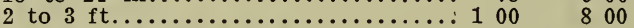

Halesia tetraptera, Silver Bell

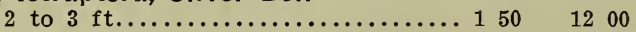

Hamamelis Virginica, Wych-hazel

18 to 24 in..................... 1251100

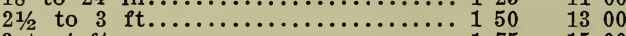

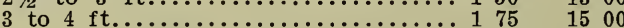

\section{HIBISCUS MEEHANI VARIEGATA}

\section{NEW SINGLE FLOWERED VARIEGATED LEAVED ALTHAEA}

This is a new variety of the variegated leaved Althaea, the foliage showing the white and yellow variegation of the old variety, but which differs from the old variety inasmuch as the flowers open wide, and in a strong vigorous plant they are about four to five inches in diameter, while on the old variety the flowers do not open at all, but look like purple buttons.

The flower is of a purplish red color, single, and the plant blooms profusely.

This new variety of our common garden Althaea will be found perfectly hardy everywhere the old variety has proven so.

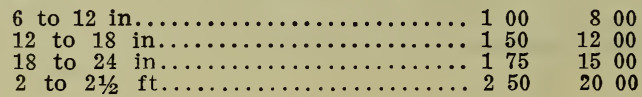


Hibiscus alba plena, Double White Althaea

Per 10 P'er 100 Per 1000

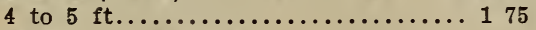

" ardens, Double Blue

18 to 24 in.................. $85 \quad 700$

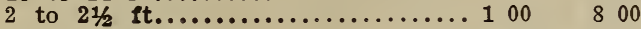

" bicolor, Double Pink

18 to 24 in.................. $85 \quad 700$

"Boule de Feu, Double Red

18 to 24 in ................... $85 \quad 700$

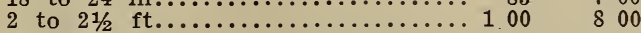

" coerulea. Double Blue

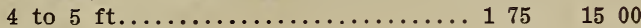

"Double White

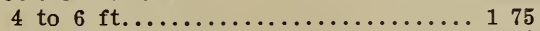

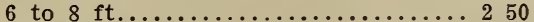

" Duc de Brabant, Double Red

18 to 24 in................. $85 \quad 700$

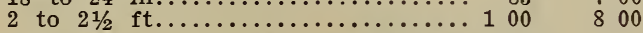

" elegantissima, Double, delicate pale pink

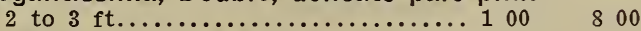

“ Jean d'Arc, Double White

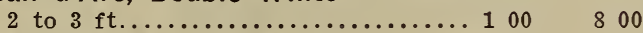

" Lady Stanley, Double Pink

18 to 24 in................... $85 \quad 700$

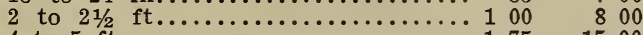

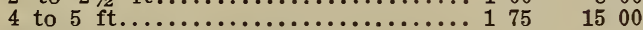

" rosea plena, Double Red

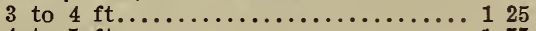

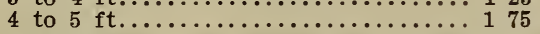

" single Pink

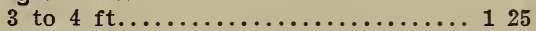

" totus alba

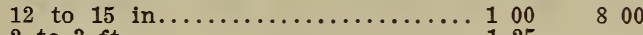

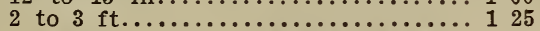

" variegata, fl. pl., Variegated-leaved, double red

18 to 24 in..................... $100 \quad 800$

Hippophaea rhamnoides, Sea Buckthorn

2 to $3 \mathrm{ft} . \ldots \ldots \ldots \ldots \ldots \ldots \ldots \ldots . \ldots \ldots$

Hydrangea arborescens

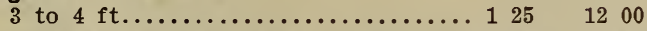

" arborescens grandiflora (new) American Everblooming Hydrangea

15 to 30 in................... $350 \quad 3000$

" paniculata (type), Single

18 to 24 in.................... $100 \quad 800$

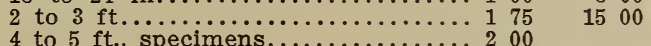

4 to $5 \mathrm{ft}$., specimens.................... 5 2 00

" paniculata, Early Flowering (type), Single

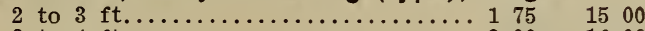

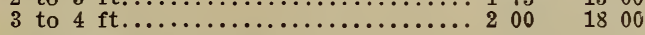

" paniculata grandiflora

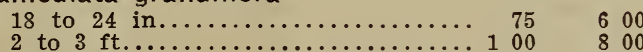

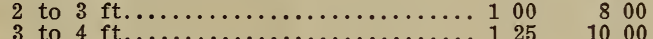

3 to $4 \mathrm{ft}$., specimens................... 200

" paniculata grandiflora Standards

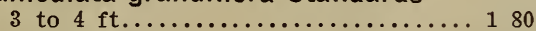

Hypericum aureum

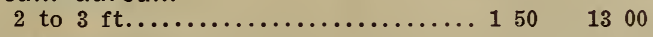

$23 \%$ densiflorum

“ Moserianum

12 to 18 in................... $125 \quad 1000$ 
Hypericum patulum

Per 10 Per 100 Per 1000 12 to 15 in................... $125 \quad 1000$

Ilex decidua, Deciduous Holly

3 to 4 ft...................... 200

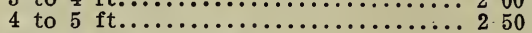

" verticillata (Prinos)

12 to 18 in..................... $100 \quad 800$

2 to 3 ft.............................. $125 \quad 1000$

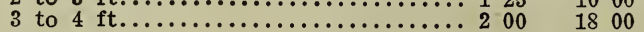

Itea Virginica

18 to 24 in................... $125 \quad 1100$

Kerria Japonica, double (Corchorus)

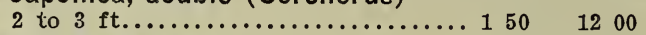

“ Japonica, single

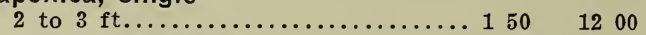

“ Japonica variegata

12 to 18 in.................... 1251000

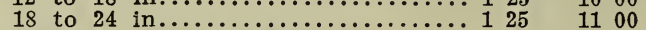

Laurus Benzoin (see Lindera)

Ligustrum amurense, Amoor Privet

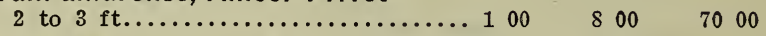

"Ibota, as commonly sold, not upright

18 to 24 in.................... $75 \quad 600 \quad 5000$

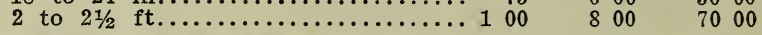

“ Ibota, upright, The True Ibota

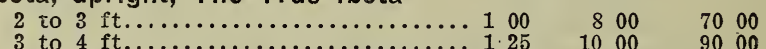

4 to $5 \mathrm{ft}$., specimens, very heavy..... 200

5 to $6 \mathrm{ft}$., specimens, very heavy....2 250

Much confusion exists in nurseries as to which is the true Ibota Privet. We claim that the true Ibota is of upright habit, but as nearly all other nurserymen claim the drooping form we only send out the upright form when orders specify that variety.

" ovalifolium

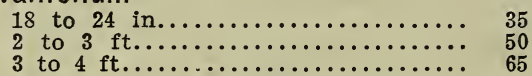

50

225

300

350

2000

2600

" Regelianum

18 to 24 in ................... 75

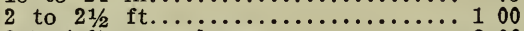

3 to $4 \mathrm{ft}$, very heavy................ 200

4 to $5 \mathrm{ft}$, very heavy............... 250

" vulgaris, Common Privet

18 to 24 in..................... $65 \quad 500 \quad 4000$

Lindera Benzoin, Spice Bush

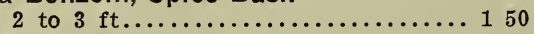

600

800

1800

2000

500

4000

Lonicera bella albida

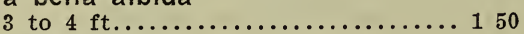

1200

1200

" bella candida

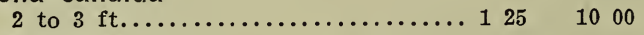

“ fragrantissima

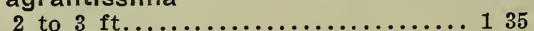

3 to 4 ft............................

1300

1500

- Morrowii

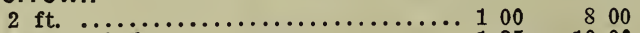

$21 / 2$ to 3 ft................................. 125

"Orientalis, White

2 to $21 / 2$ ft................... $125 \quad 1000$

“ Ruprechtiana

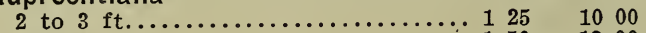

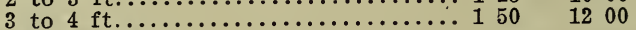

“ Tatarica, Red

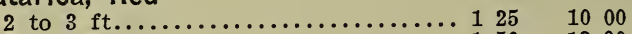

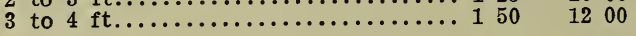


Lonicera Tatarica alba

Per 10 Per 100 Per 1000

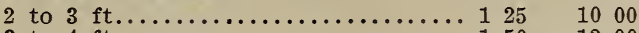

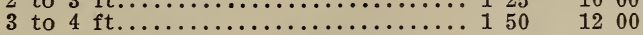

"Tatarica grandiflora rosea, Pink

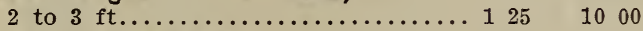

"Tatarica splendens

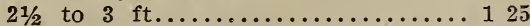

Myrica cerifera, Wax Myrtle

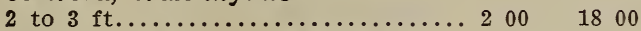

Oxydendron arboreum, Sorrel Tree

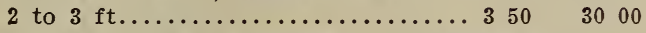

Philadelphus aureus (Syringa), Golden-leaved 12 to 18 in..................... $125 \quad 1000$

" coronarius, Sweet Flowered Mock Orange

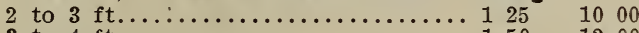

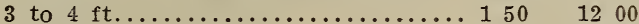

4 to 5 ft...................... $175 \quad 1500$

4 to $5 \mathrm{ft}$, specimens.................. 00

" grandiflorus, Large Flowered Mock Orange

18 to 24 in..................... $85 \quad 700$

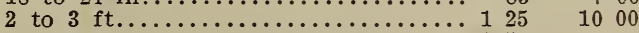

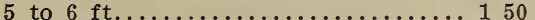

“ Lemoinei

18 to 24 in................... $100 \quad 800$

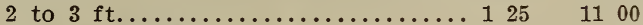

" nanus, Dwarf Mock Orange

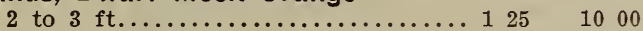

i) Zeyherii

3 to $4 \mathrm{ft} . \ldots \ldots \ldots \ldots \ldots \ldots \ldots \ldots \ldots 150 \quad 1200$

Potentilla fruticosa, Shrubby Cinquefoil

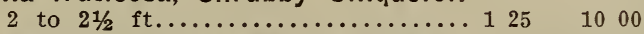

Prinos verticillata (See llex verticillata)

Prunus Japonica (See Amygdalus nana)

“ Pissardi, Purple-leaved Plum

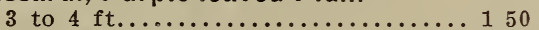

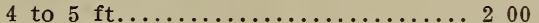

1200

“ triloba, dbl. fl. Plum

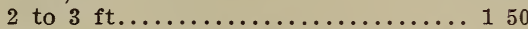

Pyracantha (see Crataegus pyracanthus)

Ptelea trifoliata, Hop Tree

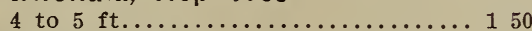

Pyrus Japonica (see Cydonia Japonica)

" arbutifolia

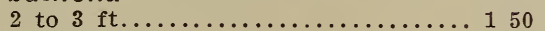

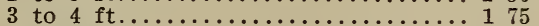

1200

“ melanocarpa

18 to 24 in.................. $125 \quad 1000$

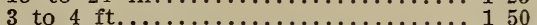

"Bechtels, and other large growing sorts (see Trees)

Rhamnus catharticus, Common Buckthorn

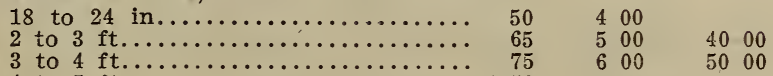

“ frangula

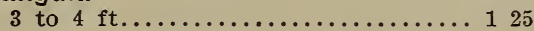

The Rhamnus catharticus makes a good strong hedge plant In such parts of the country in which California and Ibota Privets are not hardy. It is very desirable in Canada and the Northwest. 
Rhodotyphus kerroides

Per 10 Per 100 Per 1000

18 to 24 in $\ldots \ldots \ldots \ldots \ldots \ldots \ldots \ldots \ldots \ldots, 100,800$

Rhus copallina. Shining Sumach.

2 to 3 ft....................... $175 \quad 1500$

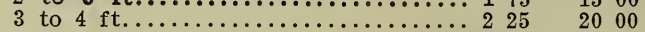

" aromatica, Sweet Sumach

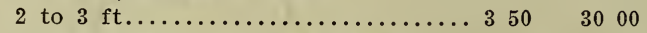

" cotinus, Mist or Smoke Tree

18 to 24 in ................... $100 \quad 800$

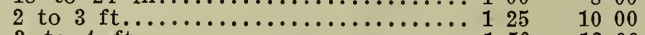

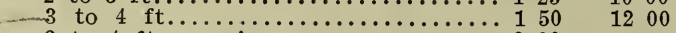

3 to $4 \mathrm{ft}$., specimens.............. 200

" glabra, Smooth Sumach

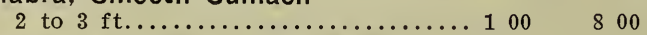

" glabra laciniata, Cut-leaved Sumach "

12 to 15 in ................... $150 \quad 1200$

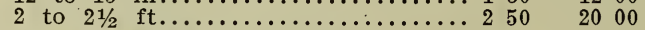

" typhina, Stag's Horn Sumach

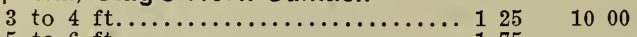

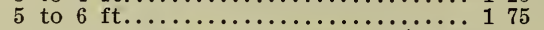

" typhina laciniata, Cut-leaved Sumach

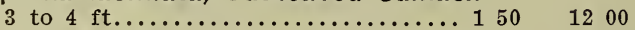

Ribes aureum, Yellow Flowering Currant

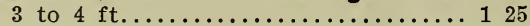

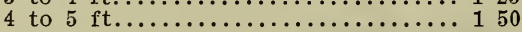

" Gordonianum, Pink Flowered Currant

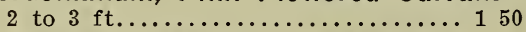

Robinia hispida rosea, Pink Rose Acacia

2 to $3 \mathrm{ft} . \ldots \ldots \ldots \ldots \ldots \ldots \ldots \ldots \ldots \ldots \ldots$

Rosa blanda

18 to 24 in.................. $125 \quad 1000$

- Carolina

18 to 24 in.................. $125 \quad 1000$

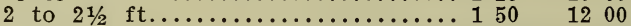

“ lucida

18 to 24 in.................... $125 \quad 1000$

" multiflora Japonica

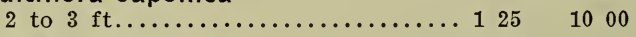

" nitida

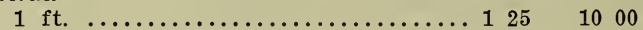

" rubiginosa, Sweet Brier

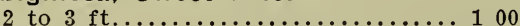

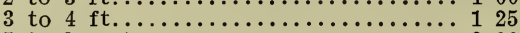

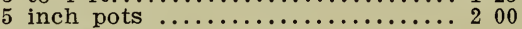

“ rubrifolia

18 to 24 in.................... $125 \quad 1000$

“ rugosa, Red

18 to 24 in.................. $100 \quad 900$

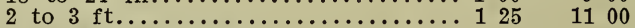

- rugosa alba, White

18 to 24 in................... $125 \quad 1100$

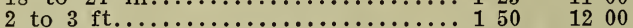

"Conrad Ferdinand Meyer, Double Shell Pink

2 year ........................ $175 \quad 1500$

"Mme. Geo. Bruant, Double White

2 year strong .................. $150 \quad 1300$

6 inch pots ......................... 250

"Hansa. Double, Velvety Red

2 year ........................ $150 \quad 1300$

" setigera. Prairie Rose

2 to 3 ft................... $125 \quad 1000$ 
Rosa spinossissima, Scotch Rose

5 inch pots .................. 250

"Baby Rambler

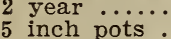
150
1200

\section{CLIMBING AND PILLAR ROSES}

\section{Rose, Baltimore Belle, Double White}

2 to $3 \mathrm{ft} . \ldots \ldots \ldots \ldots \ldots \ldots \ldots \ldots \ldots \ldots \ldots \ldots, 25$

5 inch pots $\ldots \ldots \ldots \ldots \ldots \ldots \ldots \ldots, 200$

"Crimson Rambler

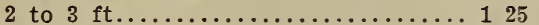

"Mad. Plantier

2 to $3 \mathrm{ft} . \ldots \ldots \ldots \ldots \ldots \ldots \ldots \ldots \ldots \ldots \ldots$

5 inch pots $\ldots \ldots \ldots \ldots \ldots \ldots \ldots \ldots, 200$

1000

“Philadelphia Rambler

5 inch pots..................250

"Pink Rambler

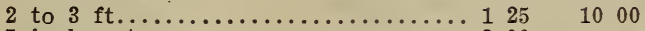

"Queen of Prairie, Double Pink

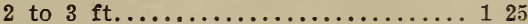

5 inch pots ........................

"White Rambler

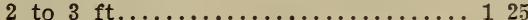

5 inch pots ....................... 00

"Yellow Rambler

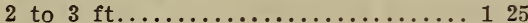

5 inch pots ...................... 200

WICHURAIANA AND HYBRIDS

\section{Rosa Wichuraiana, Memorial Rose}

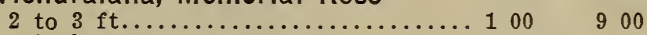

" Dorothy Perkins

5 inch pots $\ldots \ldots \ldots \ldots \ldots \ldots \ldots \ldots 200$

2 to $3 \mathrm{ft}$

"Evergreen Gem

2 to $3 \mathrm{ft} . \ldots \ldots \ldots \ldots \ldots \ldots \ldots \ldots \ldots 1251000$

"Gardenia

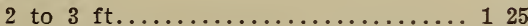

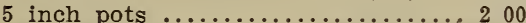

1000

"Jersey Beauty

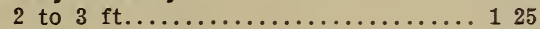

" Manda's Triumph

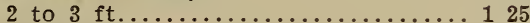

5 inch pots .................. 200

"Pink Roamer

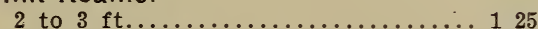

5 inch pots .................... 200

"South Orange Perfection

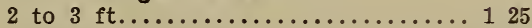

5 inch pots ....................2 00

1000

“

Universal Favorite

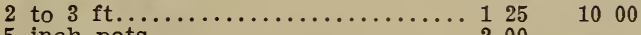

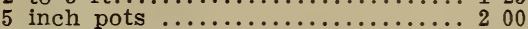

\section{ROSES-HYBRID PERPETUAL, Etc.}

2 year, budded, our selection of varieties .................... $150 \quad 1200$

2 year, budded, customers' selection. $200 \quad 1500$

See List of Varieties next page 


\section{LIST OF VARIETIES.}

COQUETTE DES ALPS, white.

FRAU CARL DRUSCHKI pure white.

GRUSS AN TEPLITZ, dark, rich crimson.

GEN. JACQUIMINOT, brilliant crimson.

HERMOSA, pink.

KAISERIN AUGUSTE VICTORIA, white, yellow centre.

LA FRANCE, silvery pink.

MAGNA CHARTA, pink, suffused with carmine.

MAMON COCHET, pink.

MAMON COCHET, white.

MARGARET DICKSON, white, pale flesh centre.

MRS. JOHN LAING, soft pink.

MRS. R. G. SHARMAN CRAWFORD, deep rosy pink. PAUL NEYRON, deep rose.

PERSIAN YELLOW, bright yellow.

PRINCE CAMILLE de ROHAN, velvety crimson.

ULRICH BRUNNER, brilliânt cherry red.

\section{Rụbus Canadensis}

Per 10 Per 100 Per 1000

2 to $3 \mathrm{ft}$....

125

1000

Sambucus aureus, Golden Elder

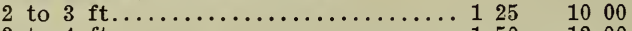

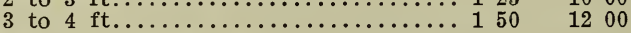

“ Canadensis, Elderberry

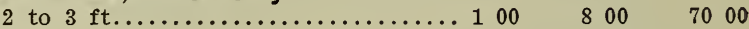

" nigra

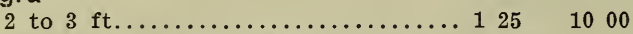

" nigra laciniata, Cut-leaved Elder

2 to $3 \mathrm{ft} . \ldots \ldots \ldots \ldots \ldots \ldots \ldots \ldots \ldots 150 \quad 1200$

“ racemosa, Red-berried Elderberry

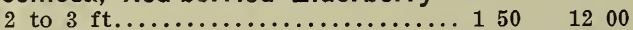

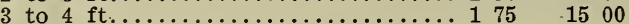

Spiraea Anthony Waterer, Pink Dwarf

18 to 24 in..................... $125 \quad 1000$

2 to $21 / 2$ ft.......................... $150 \quad 1200$

" arguta

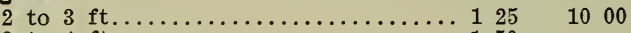

" Billardi, Pink

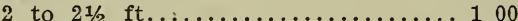

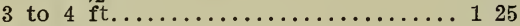

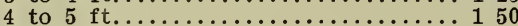

"bumalda

2 to $2 \frac{1}{2}$ ft................... 125

" callosa alba, Dwarf White

18 to 24 in.................... $125 \quad 1000$

" callosa superba

18 to 24 in.................... $125 \quad 1000$

" carpinaefolia

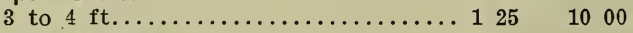

" Douglassi rosea

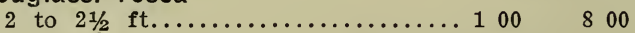

"Lindleyana

2 to $3 \mathrm{ft} . \ldots \ldots \ldots \ldots \ldots \ldots \ldots \ldots \ldots$

800

$\begin{array}{rr}10 & 00 \\ 12 & 00\end{array}$

"opulifolia, White

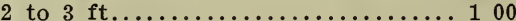

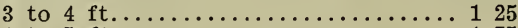

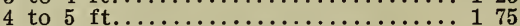

“ opulifolia aurea, Golden Leaf

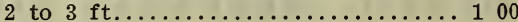

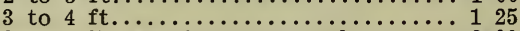

3 to 4 ft., specimens, very heavy....2 00

4 to $5 \mathrm{ft}$., specimens, very heavy.... 250

4

paniculata

3 to $4 \mathrm{ft}$ 
Spiraea prunifolia, Bridal Wreath

Per 10 Per 100 Per 1000

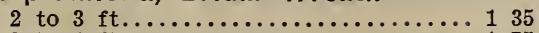

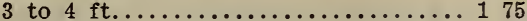

“Reevesii, single

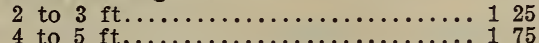

3 to $4 \mathrm{ft}$, specimens............. 200

"Reevesii, double

2 to $2 \frac{1 / 2}{f t} . \ldots \ldots \ldots \ldots \ldots \ldots \ldots \ldots \ldots$

“Regeliana

3 to $4 \mathrm{ft} . \ldots \ldots \ldots \ldots \ldots \ldots \ldots \ldots \ldots$

" salicifolia, White

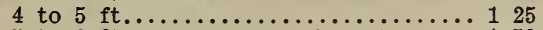

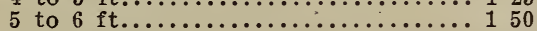

- sorbifolia

12 to 18 in....................... 100

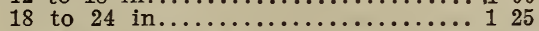

"Thunbergii, White

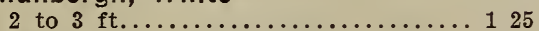

"tomentosa, Pink

2 to 3 ft..................... 125

- vaccinifolia

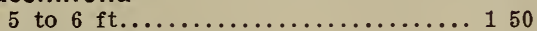

“Van Houttei, White

18 to 24 in................... 75

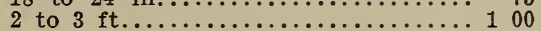

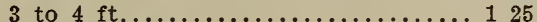

Staphyllea bumalda

2 to $2 \frac{1}{2}$ ft.................... 125

Stephanandra flexuosa

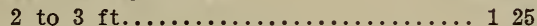

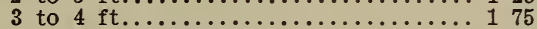

3 to $4 \mathrm{ft}$., specimens................ 200

Styrax Japonica

2 to $3 \mathrm{ft} . \ldots \ldots \ldots \ldots \ldots \ldots \ldots \ldots \ldots \ldots \ldots \ldots \ldots \ldots$

3 to $4 \mathrm{ft}$, specimens.............. 200

5 to $6 \mathrm{ft}$., specimens................ 250

Symphoricarpos racemosus, White Snowberry 18 to 24 in ..................... 100

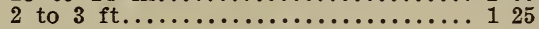

" vulgaris, Indlan Currant

2 to $21 / 2$ ft.................... 100

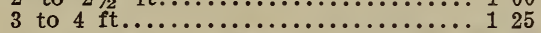

Syringa Japonica, Japanese Tree Lilac

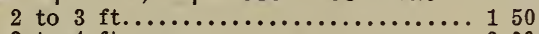

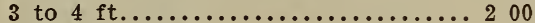

" Josikaea, Violet

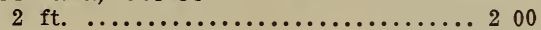

" oblata

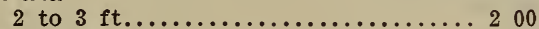

“Pekinensis

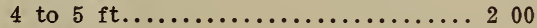

"Persica alba

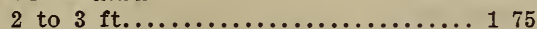

"Rothomagensis (Chinensis), Red Persian

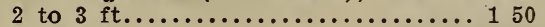

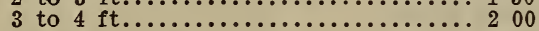

" villosa, purplish white

2 to 3 ft...................... 200

“ vulgaris, Common Purple Lilac

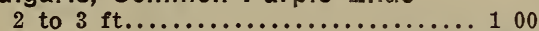

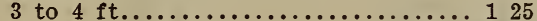

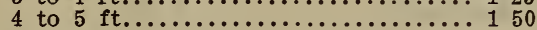

"vulgaris alba, Common White Lilac

2 to $3 \mathrm{ft} . \ldots \ldots \ldots \ldots \ldots \ldots \ldots \ldots \ldots \ldots \ldots \ldots \ldots \ldots \ldots$

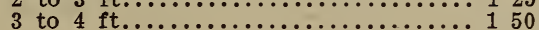

1300

1500

1000

1000

1000

1200

800

1000

1200

1000

600

800

1000

1000

1500

1500

800

1000

800

1000

$70 \quad 00$ 


\section{NEW LILACS}

\section{White, Red and Purple, Single and Double}

Per 10 Per 100 Per 1000 Eyringa Alphonse Lavallee, Double Blue, extra large panicles

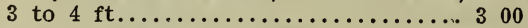

"Chas X, Reddish purple

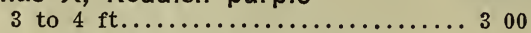

* Lovaniensis, Single, Silvery pink

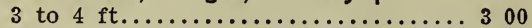

" Marie Legray, Dwarf Single White

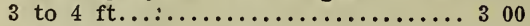

" Madame Abel Chatney, Double, Pure White

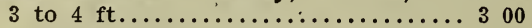

" Madame Lemoine, Double White

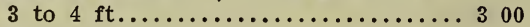

- Senator Volland, Double Rosy red

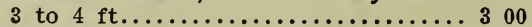

"Souvenir De Ludwig Spaeth, Single, Dark purplish red 3 to $4 \mathrm{ft} . . . \ldots \ldots \ldots \ldots \ldots \ldots . \ldots . \ldots . \ldots 30$

Tamarix Africana

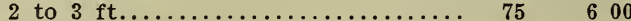

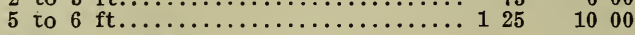

"Gallica

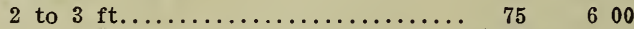

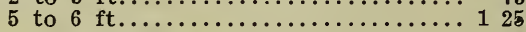

" Japonica plumosa

2 to $3 \mathrm{ft} . \ldots \ldots \ldots \ldots \ldots \ldots \ldots \ldots \ldots \ldots$. $75 \quad 600$

“ Odessana

18 to 24 in .................. $65 \quad 500$

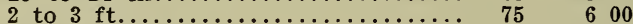

" tetrandra purpurea

3 to $4 \mathrm{ft} . \ldots \ldots \ldots \ldots \ldots \ldots \ldots \ldots \ldots \ldots, 75 \quad 600$

Viburnum acerifolium, Maple leaved

2 to $21 / 2$ ft.................... 200

" cassinoides

2 to $21 / 2$ ft.................... $200 \quad 1800$

$21 / 2$ to 3 ft..................... $250 \quad 2000$

" dentatum, Arrow Wood

18 to 24 in.................. $100 \quad 800$

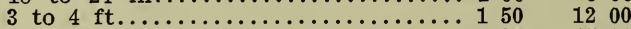

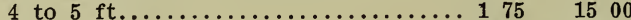

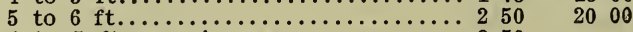

4 to $5 \mathrm{ft}$, specimens............. 250

5 to $6 \mathrm{ft}$., specimens............. 300

"dentatum Molle

18 to 24 in.................... $100 \quad 800$

2 to $21 / 2$ ft...................... $125 \quad 1000$

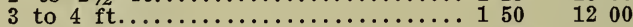

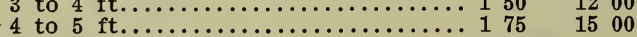

" Japonicum (Sieboldi)

18 to 24 in .................... 150

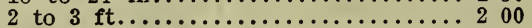

" lantana, Hobble Bush

18 to 24 in.................. 100

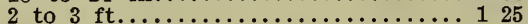

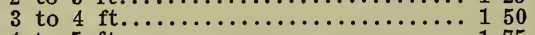

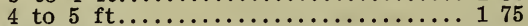

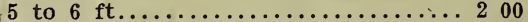

3 to $4 \mathrm{ft}$, specimens................ 200

4 to $5 \mathrm{ft}$., specimens............. 50

1800

800

1200

1500

2000

“ lentago

18 to 24 in................... $175 \quad 1500$

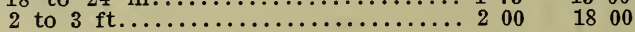


Viburnum nudum

Per 10 Per 100 Per 1000

18 to 24 in.................... $150 \quad 1300$

“ opulus sterilis, Common Snowball

18 to 24 in.......................... $100 \quad 800$

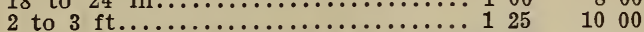

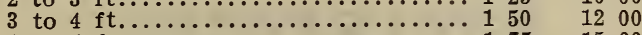

4 to 5 ft.............................. 175 15 00

" oxycoccos (opulus), High Bush Cranberry

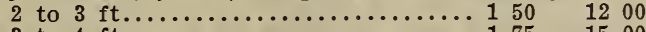

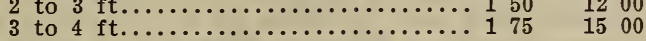

“ plicatum, Japanese Snowball (true)

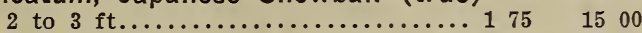

3 to 4 ft............................... $2200 \quad 2_{20} 00$

" plicatum rotundifolium

18 to 24 in..................... $125 \quad 1000$

" prunifolium, Black Haw

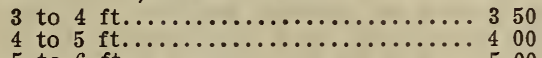

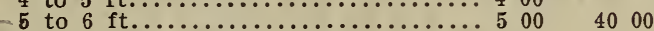

“ Sieboldi (See Japonicum)

" tomentosum

18 to 24 in.................. $125 \quad 1000$

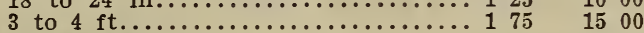

Vitex Agnus Castus, Blue

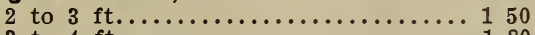

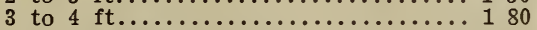

Weigela arborea versicolor, Pink

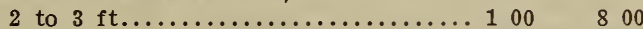

" candida, White

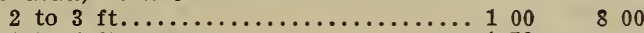

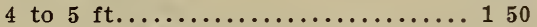

4 to $5 \mathrm{ft}$, specimens.............. 200

“ Desboisii, Dark pink

2 to $21 / 2$ ft.................... 125

"Eva Rathke, Crimson

2 to $2 \frac{1}{2}$ ft................... $125 \quad 1100$

" nana variegata

18 to 24 in.................... $100 \quad 800$

" rosea, Pink

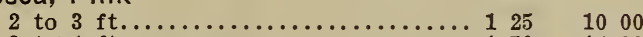

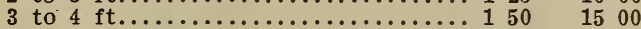

Zanthorhiza apiifolia, Yellow Root

2 year ......................... 1251000

Zanthoxylon Americanum, Prickly Ash

2 to $3 \mathrm{ft} \ldots \ldots \ldots \ldots \ldots \ldots \ldots \ldots \ldots \ldots 151500$ 


\section{Evergireens}

All of our evergreens are specimens. Every tree is given careful attention and such varieties as Retinisporas, etc., requiring it, are sheared as often as necessary in order to produce a bushy symetrical tree. They are all branched to the ground. We frequently transplant our evergreens and in that way, we get a mass of fibrous roots. In nearly every case, as noted in the catalogue, the trees will be dug with a ball of earth and the ball sewed in burlap. This makes the transplanting of them almost an assured success. Of course, the first cost of these evergreens dug and handled in this way, is more than common, but as the planter has practically no loss with them, he is saving money in the long run. Our stock must not be confused with low priced evergreens rarely transplanted and grown thickly together.

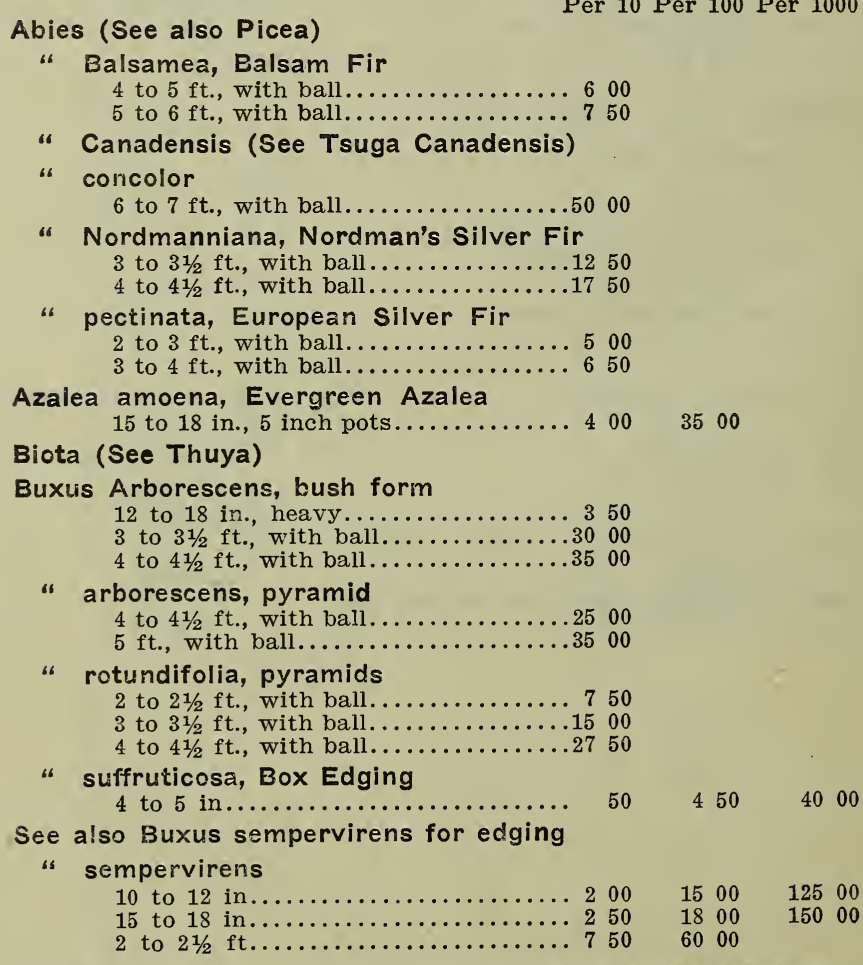

The 10 to 12 and 15 to 18 inch plants have been especially grown for edging purposes where an immediate edging of this height is required. Set about two plants to 1 foot and sheared to an even height, they will give the appearance of an edging which has been planted some time. Each plant carries a smal! ball of earth. 
Calluna vulgaris, Heath

Per 10 Per 100 Per 1000

$1 \mathrm{ft}$., bushy, 6 in. 250

2000

Crataegus pyracantha Lalandi

2 to $3 \mathrm{ft}$, 5 inch pots............. 350

Cupressus Lawsoniana Allumi, Blue Cypress

3 to $4 \mathrm{ft}$., with ball................ 850

4 to $5 \mathrm{ft}$, with ball............... 1000

Daphne cneorum

6 to 8 in., with ball............. 400

3500

Erica stricta

$1 \mathrm{ft}$., bushy, 5 inch pots........... 250

2000

" vagans capitata

$1 \mathrm{ft}$., bushy, 5 inch pots........... $250 \quad 2000$

Juniperus communis, upright form

$11 / 2$ to $2 \mathrm{ft}$, with ball.............. 350

$2 \frac{1}{2}$ to $3 \mathrm{ft}$, with ball............ 500

" communis Waukegan trailing

18 to 24 in...................... 350

2 to $2 \frac{1}{2}$ ft.................... 400

" Hibernica, Irish Juniper

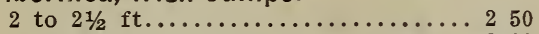

$21 / 2$ to 3 ft...................... 300

4 to $5 \mathrm{ft}$., specimens, with ball...... 500

20, 00

2500

“ Japonica aurea, Golden Juniper

3 to $3 \frac{1}{2} \mathrm{ft}$., with ball.............15 00

"Sabina

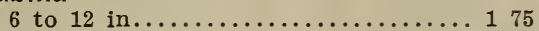

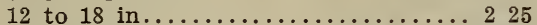

18 to 24 in....................... 300

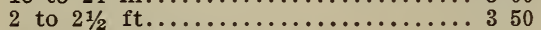

"simensis argentea variegata

6 to $6 \frac{1}{2} \mathrm{ft}$., specimens, with ball....40 00

" suecica compacta

12 to 18 in ....................... 175

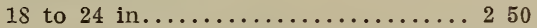

2 to $2 \frac{1}{2}$ ft.................... 350

" stricta, Pyramidal Juniper

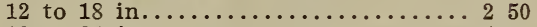

18 to 24 in.............................. 400

3 to $4 \mathrm{ft}$, with ball..............20 00

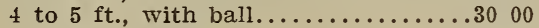

5 to $6 \mathrm{ft}$, with ball...................... 00

Visitors to our nurseries have been greatly interested and pleased with this Juniper, which has not been found in any other nursery. The habit is like a sheared pyramidal tree box. The foliage is of a bright green color, very compact and somewhat of the character of a Chinese Juniper. It makes an excellent tub plant, or for use where an evergreen of formal character is required.

"Virginiana glauca, Blue red Cedar

2 to $2 \frac{1}{2}$ ft., with ball..............15 00

3 to $31 / 2 \mathrm{ft}$, with ball...............17 50

4 to $5 \mathrm{ft}$., with ball...............20 00

Kalmia angustifolia, Narrow-leaved Mt. Laurel

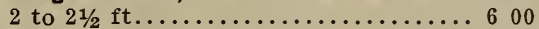

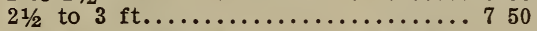

" latifolia, Broad-leaved Mt. Laurel

18 to 24 in..................... 500

2 to $2 \frac{1}{2}$ ft...................... 750

Mahonia aquifolia

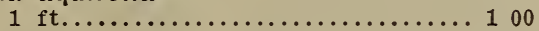

" Japonica

18 to 24 in................. 400 
Picea alba, White Spruce

Per 10 Per 100 Per 1000

2 to $3 \mathrm{ft}$., with ball................ 300

3 to $4 \mathrm{ft}$., with ball................ 400

“ excelsa, Norway Spruce

12 to 18 in...................... 125

18 to 24 in....................... 200

2 to $3 \mathrm{ft}$, with ball................. 400

3 to $4 \mathrm{ft}$., with ball................ 500

4 to 5 ft., with ball................... 750

5 to $6 \mathrm{ft}$., with ball...............17 50

“ excelsa inverta

$3 \frac{1}{2}$ to $4 \mathrm{ft}$., specimens, with ball....15 00

$41 / 2$ to $5 \mathrm{ft}$., specimens, with ball....20 00

$51 / 2$ to $6 \mathrm{ft}$., specimens, with ball....25 00

$61 / 2$ to $7 \mathrm{ft}$., specimens, with ball.....30 00

$7 \frac{1}{2}$ to $8 \mathrm{ft}$., specimens, with ball.....35 00

“ nigra Doumetti

$21 / 2$ to $31 / 2 \mathrm{ft}$., with ball............17 50

“ Orientalis, Oriental Spruce

2 to $2 \frac{1 / 2}{\mathrm{ft}}$, with ball...............10 00

4 to $4 \frac{1}{2} \mathrm{ft}$., with ball................25 00

“ pungens, Koster's Blue Spruce, Selected Blue

$11 / 2$ to $2 \mathrm{ft}$, with ball..............15 00

$21 / 2 \mathrm{ft}$, with ball....................25 00

$3 \mathrm{ft}$., specimens, with ball............30 00

Pinus cembra, Swiss Stone Pine

2 to $2 \frac{1}{2}$ ft., with ball...............10 00

3 to $3 \frac{1}{2} \mathrm{ft}$., with ball.................12 50

“ excelsa, Himalayan Pine

3 to $4 \mathrm{ft}$., with ball...............15 00

4 to $5 \mathrm{ft}$, with ball..................17 50

" strobus, White or Weymouth Pine

18 to 24 in........................ 200

2 to $3 \mathrm{ft} . \ldots \ldots \ldots \ldots \ldots \ldots \ldots \ldots \ldots, 300$

6 to $8 \mathrm{ft}$., with ball...............20 00

“ strobus nana, Dwarf White Pine

12 to 18 in. broad, with ball.........12 50

Pyracantha (see Crataegus Pyracantha)

Retinispora eriocoides

12 to 18 in..................... 150

“ filifera

2 to $2 \frac{1}{2} \mathrm{ft}$, with ball............ 750

$21 / 2$ to $3 \mathrm{ft}$, with ball................ 900

3 to $31 / 2 \mathrm{ft}$., with ball............... 50

4 to $41 / 2$ ft., with ball.............. 00

5 to $51 / 2 \mathrm{ft}$. , with ball................... 00

“ filifera aurea

$11 / 2$ to $2 \mathrm{ft}$, with ball...............10 00

2 to $21 / 2 \mathrm{ft}$., with ball................. 50

is Lycopoides

$21 / 2$ to $3 \mathrm{ft}$, with ball............15 00

“ obtusa compacta

18 to 24 in., with ball.............. 300

2 to $2 \frac{1}{2} \mathrm{ft}$, with ball............. 500

$21 / 2$ to $3 \mathrm{ft}$., with ball................ 750

$3 \frac{1 / 2}{2}$ to $4 \mathrm{ft} .$, with ball..............15 00

“ Disifera

6 to $7 \mathrm{ft}$., specimens, with ball.....25 00

8 to $9 \mathrm{ft}$., specimens, with ball........30 00

9 to $10 \mathrm{ft}$., specimens, with ball.....35 00

10 to $11 \mathrm{ft}$., specimens, with ball.....40 00

12 to $13 \mathrm{ft}$., specimens, with ball...50 00 
Retinispora nisifera aurea, Golden

Per 10 P'er 100 Per 1000

2 to $2 \frac{1}{2} \mathrm{ft}$, with ball............ 350

$21 / 2$ to $3 \mathrm{ft}$, with ball............ 500

3 to $31 / 2$ ft., with ball............... 750

4 to $41 / 2 \mathrm{ft}$, with ball..............12 50

5 to $5 \frac{1}{2} \mathrm{ft}$, with ball.............20 00

6 to $61 / 2 \mathrm{ft}$., specimens, with ball....27 50

7 to $7 \frac{1}{2} \mathrm{ft}$., specimens with ball....3 00

8 to $81 / 2 \mathrm{ft}$., specimens, with ball......35 00

9 to $91 / 2 \mathrm{ft}$., specimens, with ball....40 00

10 to $101 / 2 \mathrm{ft}$, with ball.............50 00

«. plumosa

18 to 24 in.................... 350

2 to $3 \mathrm{ft}$, with ball................. 500

3 to $4 \mathrm{ft}$, with ball.................6 650

4 to $5 \mathrm{ft}$., with ball............... 1000

6 to $8 \mathrm{ft}$., specimens, with ball.......25 00

plumosa aurea, Golden

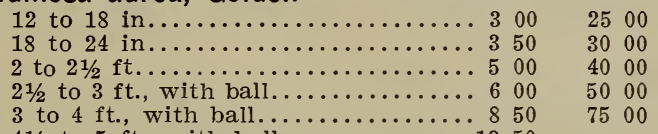

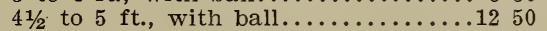

6 to $61 / 2 \mathrm{ft}$, with ball............25 00

7 to $71 / 2$ ft., with ball............... 3000

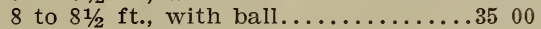

9 to $91 / 2 \mathrm{ft}$, with ball..............40 00

- squarrosa Veitchii

12 to 18 in ....................... 300

18 to 24 in ............................ 350

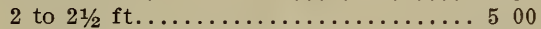

$21 / 2$ to $3 \mathrm{ft}$, with ball.............6 00

$31 / 2$ to $4 \mathrm{ft}$, with ball................. 00

4 to $5 \mathrm{ft}$, with ball............... 1500

5 to $6 \mathrm{ft}$., with ball................25 00

" squarrosa Veitchii aurea

$2 \frac{1 / 2}{2}$ to $3 \mathrm{ft}$., with ball............ 1750

Rhododendron Catawbiense

18 to 24 in...................... 1000

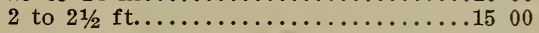

“ Maximum

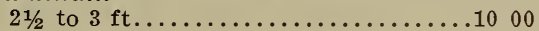

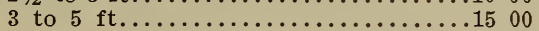

RHODODENDRONS

Hybrids, Assorted Varieties

Abraham Lincoln, crimson

18 in.......................... 850

Album Elegans, white

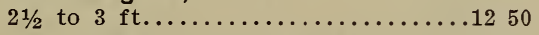

Album Grandiflorum, white

2 to $21 / 2$ ft......................10 00

Caractacus, crimson

18 to 24 in..................... 850

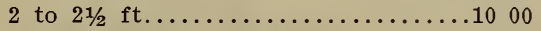

Charles Bagley, crimson

18 in...................... 850

Everestianum, rose

18 to 24 in.................... 850

General Grant, soft rosy red

18 in........................ 850

H. W. Sargent, red

18 in. 
Lady Armstrong, red

Per 10 Per 100 Per 1000 18 in........................... 850

Lady Claremont, rosy scarlet

18 in....................... 850

Mrs. Milner, rich crimson

18 in........................ 850

Parson's Gloriosa, rosy white

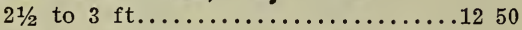

President Lincoln, lilac rose

18 to 24 in.................... 850

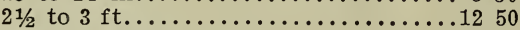

Roseum Elegans, pink

18 to 24 in..................... 850

Taxus baccata pendula, Weeping English Yew

4 to $4 \frac{1}{2} \mathrm{ft}$., with ball.............15 00

" cuspidata brevifolia

2 ft., with ball...................15 00

"Hibernica, Irish Yew

12 to 18 in.......................... 50

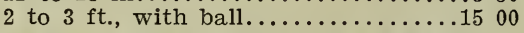

" Hibernica aurea, Golden Irish Yew

$21 / 2$ to $3 \mathrm{ft}$, with ball..............15 00

3 to $3 \frac{1}{2} \mathrm{ft}$, with ball.................... 50

Thuya Hoveyii, Hovey's Golden Arbor Vitae

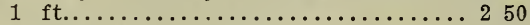
2 to $2 \frac{1}{2} \mathrm{ft}$., with ball............. 500

" occidentalis, American Arbor Vitae

3 to $4 \mathrm{ft}$, with ball.............6 $600 \quad 5000$

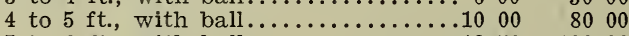

5 to $6 \mathrm{ft}$, with ball...............12 $50 \quad 10000$

$7 \mathrm{ft}$., with ball..................15 $00 \quad 13500$

" occidentalis George Peabody, Golden Arbor Vitae

3 to $31 / 2 \mathrm{ft}$., with ball................10 00

4 to $4 \frac{1}{2} \mathrm{ft}$, with ball............... 50

6 to $61 / 2 \mathrm{ft}$, with ball............... 50

7 to $71 / 2 \mathrm{ft}$, with ball............20 00

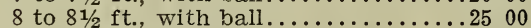

9 to $9 \frac{1}{2} \mathrm{ft}$, with ball..............30 00

" occidentalis globosa, American Globe Arbor Vitae

12 to 18 in........................ $50 \quad 2000$

18 to 24 in., with ball............ 500

" occidentalis pyramidalis, Pyramidal Arbor Vitae

2 to $21 / 2 \mathrm{ft}$, with ball............4 $400 \quad 3500$

$21 / 2$ to 3 ft., with ball............... $500 \quad 4000$

4 to $5 \mathrm{ft}$. with ball...............12 $50 \quad 10000$

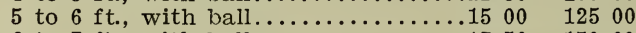

6 to $7 \mathrm{ft}$, with ball................. $50 \quad 150 \quad 00$

"occidentalis spiralis

3 to $4 \mathrm{ft}$, with ball............ $750 \quad 6000$

" occidentalis Vervaeneana, Golden Variegated

18 to 24 in........................ 350

2 to $3 \mathrm{ft}$, with ball.............. 650

3 to $4 \mathrm{ft}$., with ball.............. 850

" (Biota) Orientalis nana aurea, Berckmans type

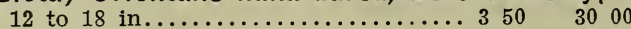

18 to 24 in.................. $500 \quad 4000$

“ plicata, Fern-leaved

12 to 18 in ............................ $50 \quad 2000$

18 to 24 in........................... $350 \quad 3000$

- Siberica, Siberian Arbor Vitae

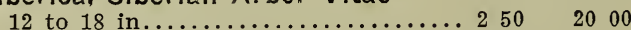

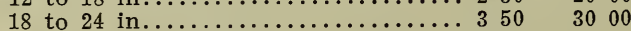

2 to $21 / 2 \mathrm{ft}$, with ball............. 500

$21 / 2$ to $3 \mathrm{ft}$, with ball............6 600 
Tsuga canadensis, Hemlock

Per 10 Per 100 Per 1000

$21 / 2$ to $3 \mathrm{ft}$., with ball........... 750

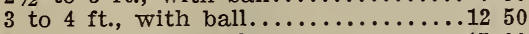

4 to $5 \mathrm{ft}$, with ball..............15 00

5 to $6 \mathrm{ft}$, with ball..............17 50

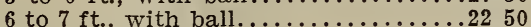

7 to $8 \mathrm{ft}$., with ball...............25 00

8 to $10 \mathrm{ft}$., with ball......................... 00

Yucca filamentosa, Adam's Needle

5 year ...................... $75 \quad 600$

\section{Vines and Climbers}

For Spring planting, our "pot-grown vines" are much more desirable than field grown stock. They have been established in pots for a year and they are heavily rooted. We introduced this method of growing vines many years ago and customers now prefer it to field-grown stock for Spring work. When shipping, we knock them out of the clay pots and send in paper pots.

Actinidia arguta

Per 10 P'er 100 Per 1000

5 inch pots.................. 200

Akebia quinata

5 inch pots................... 200

Ampelopsis Veitchii, Japan or Boston Ivy

2 year .......................... 100

5 inch pots.............................. 00

800

“Englemanni

3 year .......................... 100

5 inch pots...................... 200

"Virginica (quinquefolia), Virginia Creeper

5 inch pots..................... 200

Aristolochia Sipho, Dutchman's pipe

3 to $4 \mathrm{ft}$., heavy.................. $300 \quad 2500$

Bignonia radicans, Trumpet Creeper

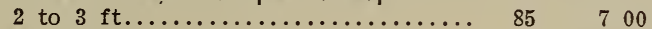

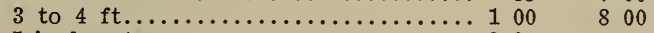

" radicans grandiflora

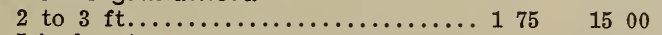

5 inch pots........................... 50

Celastris articulatus, Japanese Staff Vine

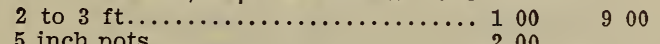

“ punctatus

5 inch pots....................200

" scandens, Staff Vine

2 to 3 ft....................... 100

6 inch pots............................ 00

Clematis paniculata

2 and 3 year................... 1251000

"Virginitana, Virgin's Bower

5 inch pots................... 200

CLEMATIS HYBRIDS

2 and 3 year, pot grown.........250

See List of Varieties next page 


\section{LIST OF VARIETIES OF CLEMATIS}

GYPSEY QUEEN. Dark blue.

HENRYII. White.

JACKMANNI. Purple.

LAWSONIANA. Light blue.

MME. ED. ANDRE. Red.

SIEBOLDII. Lavender.

Decumaria barbara

Per 10 Per 100 Per 1000

5 inch pots.................... 200

Dioscorea batatas, Chinese Yam

5 inch pots................... 200

Dolichos Japonicus

5 inch pots.................... 350

Euonymus radicans, Green-leaved

6 to 12 in...................... $75 \quad 600$

5 inch pots..................... 200

" radicans variegata

8 to 12 in...................... $75 \quad 600$

12 to 18 in ....................... $100 \quad 800$

18 to 24 in................... 125 10. 00

Hedera Helix, English ivy

5 inch pots...................200

Humulus lupulus, Hop Vine

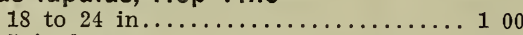

5 inch pots.................. 250

Jasminum nudiflorum, Yellow Jessamine

5 inch pots...................... 300

" officinale, White Jessamine

5 inch pots.................... 300

Lonicera brachypoda aurea, Golden Honeysuckle

2 to $3 \mathrm{ft} \ldots \ldots \ldots \ldots \ldots \ldots \ldots \ldots \ldots$. 85 . 700

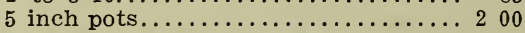

"Halleana, Hall's Honeysuckle

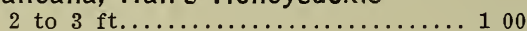

5 inch pots........................ 200

800

“Punicea

2 to $2 \frac{1}{2} \mathrm{ft} . \ldots \ldots \ldots \ldots \ldots \ldots \ldots \ldots \ldots$

800

"Red Coral

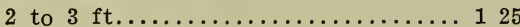

5 inch pots....................... 200

" sinensis, Chinese Honeysuckle

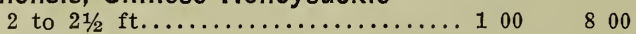

5 inch pots....................... 200

"Sullivanti

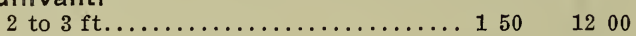

"Glauca

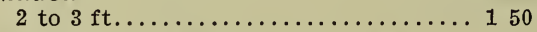

1200

Lycium barbarum, Matrimony Vine

5 inch pots..................... 200

Pueraria Thunbergiana, see Dolichos Japonicus

Roses, Climbing, Creeping and Pillar (See page 21)

Tecoma radicans (See Bignonia radicans, page 31 )

Vitis heterophylla variegata

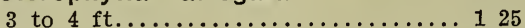

5 inch pots........................ 200

Wistaria frutescens, American Glycine

6 inch pots ..................... 350

" sinensis, Chinese Blue Wistaria

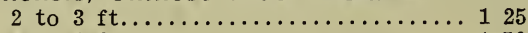

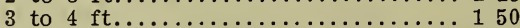

5 inch pots.......................... 350

" sinensis alba, Chinese White Wistaria

7 inch pots...................5 00 


\section{Hardy Herbaceous Perennials, Ornamental Grasses and Ferns}

The following is a list of stock we can supply in quantity. In addition, our immense collection contains many choice kinds not here mentioned.

Send us your list of wants and let us quote upon them.

We aim to grow only first class stock and send out neither old clumps of low vitality nor microscopic divisions, but young, vigorous plants that will give immediate results.

Our standard, where kind will allow, is one year, fieldgrown.

Per 10 Per 100

" Millefolium roseum, rose, July to........ $80 \quad 600$

"Ptarmica plena, "The Pearl" double, white, July ................ so 600

" tomentosa, golden yellow, July......... S0 600

Aegopodium podagraria variegata, variegated foliage ..................... so 6 vo

Agrostemma coronaria, crimson, June...... 80 б 00

Ajuga genevensis, blue, May.............. $80 \quad 600$

" reptans, blue, May............... $80 \quad 500$

Alyssum argenteum, yellow, May......... $100 \quad 800$

" saxatile compactum, golden yellow, May.. $80 \quad 600$

Amsonia salicifolia, blue, June............ $100 \quad 800$

" Tabernaemontana, clear blue, June..... $100 \quad 800$

Anchusa Italica, dark blue, June to Sept..... $100 \quad 800$

Anemone Japonica alba, white, Sept. to Nov... $80 \quad 600$

" Japonica rosea, rose, Sept. to Nov....... $80 \quad 600$

" Japonica, "Queen Charlotte," La France pink, Sept. to Nov.............. $80 \quad 600$

" Japonica, "Whirlwind," white, Sept. to Nov. $80 \quad 600$

"Japonica rubra, Brilliant, Sept. to Nov... So $\quad$ So 600

" sylvestris, white ................. $100 \quad 800$

Anthemis tinctoria, yellow, July.............. $80 \quad 600$

" tinctoria pallida, white, July...................... $80 \quad 600$

Anthericum liliastrum, white, June........ $80 \quad 6 \quad 00$

Aquilegia Canadensis, scarlet, May and June.. $\quad 80 \quad 600$

" caerulea, blue and white, May.......... $80 \quad 6 \quad 6$ i)

" chrysantha, yellow, June............. $80 \quad 600$

"flabellata nana alba, large white, June dwarf ...................... $80 \quad 600$

" Skinneri, red and yellow, May......... $80 \quad 600$

" vulgaris, blue and purple, May........ $80 \quad 600$

" vulgaris fl. pl., various, May.......... $80 \quad 600$

"vulgaris alba, white, May............ $80 \quad 6$ Do

Arabis albida, white, April............. $80 \quad 600$

Armeria maritima alba, white, May.......... $100 \quad 800$

" maritima splendens, pink, May......... $100 \quad 800$

“ plantaginea, pink, May.............................. 800

Artemisia Abrotanum, "Old Man".......... $80 \quad 600$

" pontica, "Old Woman," silver foliage..... $80 \quad 600$

" Dracunculus, "Tarragon" ............ $80 \quad 600$

"Stellariana, white and woolly leaves..... $80 \quad 600$ 
Per 10

Asclepias tuberosa, orange, July.......... 100

Aster alpina, bright purple, June and July.... 80

" amelius elegans, light blue, Sept....... 100

"amethystinus, large pale blue, Sept..... 80

“ Novae-Angliae, purple ............... 80

" Novae-Angliaea rosea, rose, Sept....... 100

“Mrs. F. W. Raynor, rose, Sept......... 100

"Novi-Belgii Robert Parker, pale blue, Sept. 100

“ Novi-Belgii St. Brigid, lavender, Sept.... 100

"Novi-Belgii Top Sawyer, lavender, Sept.. 100

"Novi-Belgii White Queen, white, Sept.... 100

" Pyrenaicus, white, July and August..... 100

" Tataricus, light purple, late fall....... 80

Baptisia Australis, blue, June.............. 100

Belamcanda Chinensis, red orange, Aug. to Sept. 75

Bellis perennis, "English Daisy," various colors. 60

Betonica orientalis, pink, July............ 100

" rosea, dwarf, pleasing pink, July......... 100

Bocconia cordata, buff, June to August......... 100

Boltonia latisquama, pale pink, Aug. to Sept.. 80

Campanula carpatica, blue, July to Sept...... 100

" carpatica alba, white, July and Sept.... 100

“ glomerata, blue, June................. 100

" grandis, blue, July.................. 100

" latifolia macrantha, blue, June.......... 100

" medium, "Canterbury Bells," blue, May

and June ................... 100

" medium alba, white, May, June........... 100

" medium calycanthema, blue, May, June... 100

“ persicifolia, blue, June and July......... 100

“ persicifolia alba, white, June and July.... 100

“ pyramidalis, blue, August............ 100

" rotunifolia, light blue, June............ 80

Cassia Marilandica, yellow, July and August... 80

Centaurea dealbata, yellow, Aug. and Sept.... 100

" macrocephala, yellow, July.......... 100

" montana, blue, June and July............ 100

" nigra variegata, golden yellow, variegated

foliage ................... 100

Cerastium tomentosum, Mouse Ear, white,

April and May ............... 80

Chrysanthemums, hardy, 2 in. pots.......... 75

Per 100

800

600
8

800

600

600

800

800

800

800

800

800

800

600

$8^{\circ} 00$

500

400

800

800

800

600

8 U.)

800

800

800

800

800

800

800

800

800

800

6 v0

600

800

800

800

800

600

500

\section{LIST OF HARDY CHRYSANTHEMUMS}

\begin{tabular}{llll}
\multicolumn{1}{c}{ NAME } & SIZE OF FLOWER & \multicolumn{1}{c}{ color } & HEIGHT \\
Autumn Queen & Large & Rosy Pink & Medium \\
Bedouin & Small & $\begin{array}{l}\text { Mixture of garnet and } \\
\text { white }\end{array}$ & Dwarf \\
Brown Bessie & Button & Beautiful Brown & IMedium \\
Eagle d'Or & Medium & Good, clear yellow & Tall \\
Edna & Medium & Glowing pink & Dwarf \\
Fire Ball & Medium & Yellow, tipped crimson & Medium \\
Flora & Small & Golden yellow & Dwarf \\
Fremy & Large & Beautiful terra cotta & Medium \\
Globe d'Or & Large & Bushy, clear yellow & Dwarf \\
Golden Mlle. Marthat & Small & Clear, orange yellow & Tall \\
Golden Pheasant & Small & Rich yellow & Medium \\
Goldfinch & Small & Gold, shaded crimson & Tall \\
Grandeur & Large & Golden bronze and old gold & Medium \\
Julia Lagravere & Large & Rich maroon & Tall \\
Kadar & Medium & Mottled crimson, garnet & Dwarf
\end{tabular}

List continued on next page. 
List of Hardy Chrysanthemums-Continued.

NAME

Ladysmith

L'Ami Conderschlerdt

Little Pet

Maid of Kent

Model

Mrs. Snyder

Mrs. Vincent

Nellie Rainsford

President

Prince Victor

Souer Melaine

St. Illoria

Strathmeath

Stratagem

Sunset

Victor
La Favorite

Iovely
SIZE OF FLOWER

Medium

Small

Small

Small

Small

Medium

Small

Large

Large

Small

Large

Large

Large

Large

Large

Large

Medium

Medium
COLOR

HEIGHT

Rosy lake, tinged salmon Tall

Sulphur white

Rosy pink, shaded white

Bright pink

White

Round, full white

Rich yellow

Magenta

Orange salmon, tipped red

Deep, violet rose

Brownish red

Fine pure white

Glorious silvery pink

Clear pink

Crimson, shaded gold

Single, reddish brown

Claret color

Tall

Tall

Tall

Tall

Tall

Tall

Tall

Tall

Tall
Claret, perfect form

Dwarf

Medium

Medium

Dwarf

Medium

Medium

Medium

Medium

Per 10 Per 100

Clematis Davidiana, blue, August.......... $125 \quad 1000$

"recta, white, July................ $150 \quad 1200$

Convallaria majalis (Lily of the Valley), white, spring, clumps .................. 00

Coreopsis lanceolata grandiflora, golden yellow,

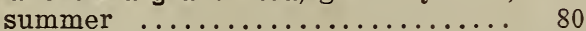

1500

600

"rosea, rose, Sept. and Oct........... 60

" senifolia, yellow, July............... 80

Coronilla varia, pink, June to Aug............ 80

Delphinium Chinense, Chinese Larkspur, blue and white, June to August.........

" elatum, English Hybrids, shades of blue,

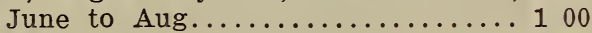

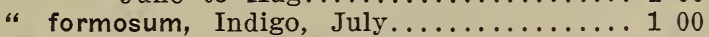

Dianthus barbatus, Sweet William, many colors, May and June ..................... 80

" plumarius, double, May and June....... 100

"Her Majesty, double white, May and June. 100

" Lord Lyons, deep pink, May and June.... 100

Dianthus Mrs. Sinkins, white, May and June.. 100

"Perpetual Snow, white, all summer...... 100

"variabilis, white, maroon mark, May and

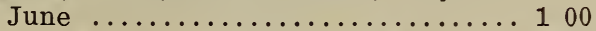

Dicentra formosa, pink, July and Aug....... 100

" spectabilis, pink, April and May....... 100

Dictamus fraxinella, red, June............ 200

"fraxinella alba, white, June.......... 200

Digitalis grandiflorus, yellow, June to July.... 100

" lanata, greyish white, June........... 100

" purpurea, purple, May and June........... 100

"f purpurea alba, white, May and June.... 100

Doronicum plantagineum excelsum, yellow, April to June ................................... 00

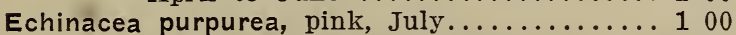

Epimedium alpinum, pink, April.......... 125

"Musschianum, rosy red, April........ 125

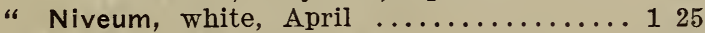

Erigeron alpinus, purple, July............ 80

Eryngium amethystinum, blue, July........ 100

Eupatorium ageratoides, white, Sept........ 100

Euphorbia corollata, white, Sept.......... 100
500

600

600

600

800

800

600

800

800

800

800

800

800

800

800

15 U0

1500

800

800

800

800

$\begin{array}{ll}8 & 09\end{array}$

800

1000

1000

1000

600

800

800

800 


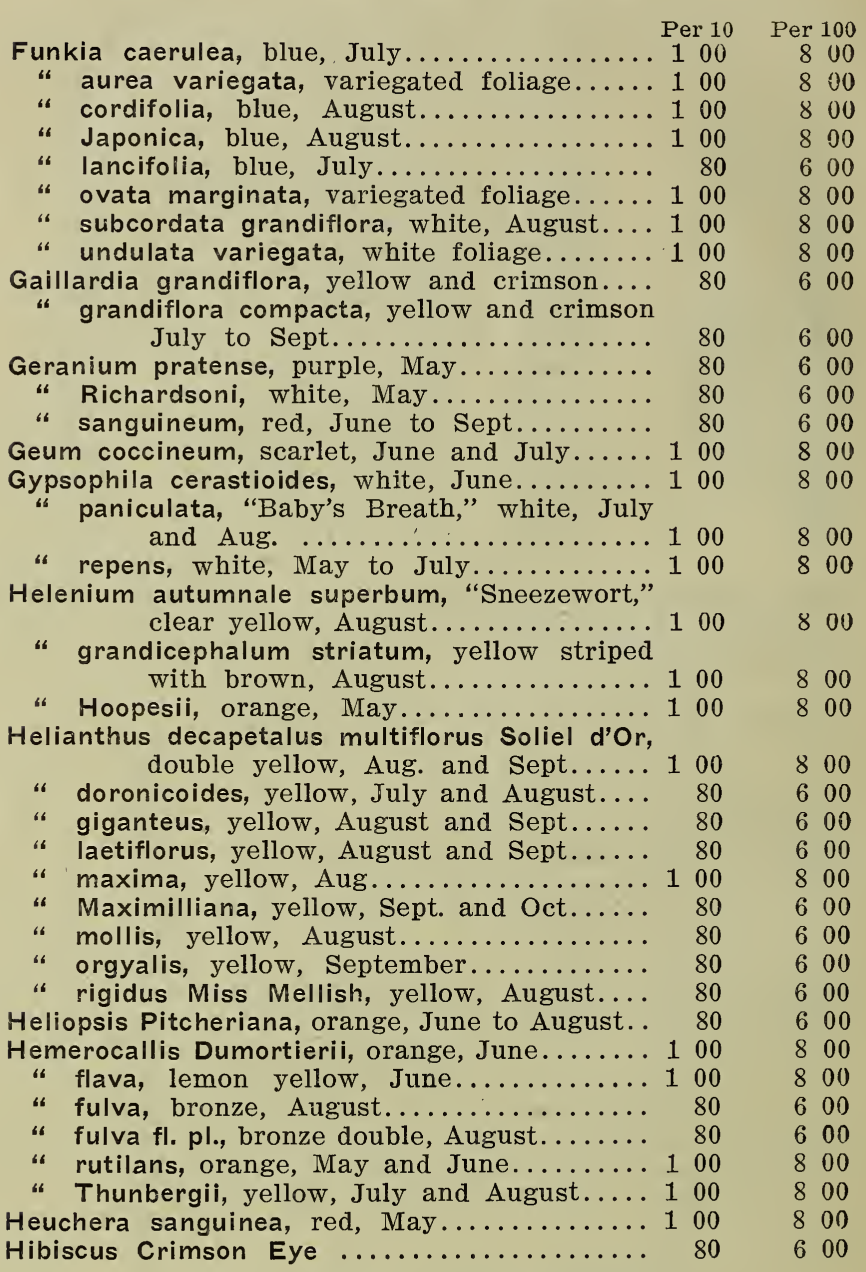

\section{MEEHANS' MALLOW MARVELS.}

The most remarkable creation of the day. Absolutely hardy in Canada. Thrives as well there as it does in the South. A plant for all sections of the country. Flowers in all shades of colors, ten inches across. Plants labeled to color as they flower. Every plant sold true to color. See full description on back cover of catalogue. New colored plate sent on application.

\section{Prices for strong two-year-old roots.}

Crimson Marvel, shades of Crimson..... 120

Red Marvel, shades of Red.......... 120

White Marvel ................... 120

Pink Marvel, shades of Pink.......... 80

Hollyhocks, double, separate colors, June to 


\begin{tabular}{|c|c|c|}
\hline & Per 10 & Per 100 \\
\hline Hyacinth & 25 & 200 \\
\hline white, A & 80 & \\
\hline low, July. . & 100 & \\
\hline , deep lavende & 80 & \\
\hline & & \\
\hline flo & & \\
\hline Germanica, best assortment of varieties. & 80 & \\
\hline
\end{tabular}

\section{LIST OF IRIS GERMANICA}

COELESTINE. Lavender.

JEWELL. Dwarf, dark purple.

JOSEPHINE. Purple.

LADY ALICE. Lavender and purple.

LADY STUMPP. Blue and lavender.

LA TENDRE. Buff and purple.

MAD. CHEREAU. Lavender and white.

QUEEN OF MAY. Pink.

SILVER KING. White.

YOLANDE. Deep purple.

Iris laevigata (Kaempferi) Japanese, July.... 12

\section{LIST OF JAPANESE IRIS}

Twenty superb varieties, representing the cream of the hundreds of sorts of this beautiful flower. No two varieties exactly alike. Single and double. The wonderful I ris Kaempferi, the "Flower of Japan," is one of the most beautiful and characteristic flowers ever introduced. Words cannot describe their gorgeous colorings, their delicate tints and unique forms. There are hundreds of named varieties in cultivation, but many of the flowers are identical.

\section{Double}

NYMPHEA. White, shaded lilac.

YEDDO. Dark red violet.

TO KWANG. Clear blue.

KAWATAKA-GIAHASHO. White, veined lilac.

HISHIKAWA-MARON CU. White, very double.

HOKUSAI. Black-blue, very double.

KORIN. Violet, center white and yellow.

OKUMARU. Pale blue.

NIPPON. White, center yellow.

YOWROSHIMA. Violet, blotched white.

MOTONOBU. Clear white.

\section{Single}

GENERAL OYAMA. White, pale red-violet.

FLAMINGO. White veined rose-red.

LADA-MARU. White.

GENERAL TUCKHISSIMA. Blue, center white, veined.

KASAGI. Pale violet, veined white.

PECCO. White violet.

CONFUCIUS. White, red violet veined, center purple.

NAKATENDO. Violet and white.

SHIMONURO-KENZAI. Dark violet, shaded white.

I ris pallida speciosa, indigo, May.......... $80 \quad 600$

" prismatica, white, tinted various colors, June ................... $100 \quad 800$

“

pumila, various, April............. 80

600

Siberica orientale, indigo blue, June..... $100 \quad 800$

spectabilis, blue, June ............. $80 \quad 600$

stenophylla, blue, June.............. $80 \quad 600$

" tectorum, lavender, June............ $100 \quad 800$

Lamium purpureum variegatum, pink, May.. $80 \quad 600$ 
Lathyrus grandiflorus, pink and white, June

Per 10 Per 100

to August ................. $150 \quad 1200$

Lavandula vera, lavender, July and Aug..... $100 \quad 800$

" spica, lavender, July and August........ $100 \quad 800$

Liatris pycnostachia, purple, August and Sept.. $\quad 80 \quad 600$

“ spicata, purple, Aug. and Sept......... $80 \quad 600$

Lilium candidum, "Annunciation Lily," white,

June ..................... $100 \quad 800$

" auratum, Gold-banded of Japan, white spotted, July ................ 150

“ elegans, yellow, July and August......... 150

“ speciosum album, white, August and Sept. 150

“ speciosum roseum, rose, August and Sept. 150

" superbum, orange red, July and August.. 80

" tigrinum splendens, "Tiger Lily," orange spotted, August .............. 80

Linum perenne, blue, June.............. 80

Lobelia cardinalis, scarlet, Aug. and Sept..... 100

Lotus corniculatus, yellow, June to Oct..... 80

Lychnis chalcedonica, scarlet, July........ 80

“ Flos-cuculi, red, May.............. 80

“ Flos-Jovis, scarlet, May............. 80

“ viscaria splendens, red, July......... 80

Lysimachia clethroides, white, July to Sept.... 80

" verticillata, yellow, July............ 80

“ vulgaris, yellow, August.............. 80

Lythrum salicaria, purple, June and July..... 80

“ Japonicum elatum, purplish red, June and July ...................... $80 \quad 600$

“ roseum superbum, purple, June and July.. $100 \quad 800$

Monarda didyma splendens, scarlet, Aug. to

Sept. .......................... $80 \quad 600$

" fistulosa alba, white, Aug. and Sept..... $80 \quad 600$

“ fistulosa purpurea, purple, Aug. and Sept. $\quad 80 \quad 600$

" mollis, pink, Aug. and Sept........... $125 \quad 1000$

Myosotis palustris semperflorens, "Forget-menot," blue, April and May........ $100 \quad 800$

Nepeta Glechoma variegata, blue, April and May ...................... 50

Oenothera Missouriensis, yellow, July and Aug. 80

“ speciosa, large white, June and July..... 80

"Youngii, yellow, June to Sept........... 80

Opuntia Rafinesqui, "Cactus," yellow, June..... 100

Pachysandra terminalis, evergreen, whitish, May ..................... 80

Paeonia Moutan, Tree Paeonia............ 750

"Festiva Maxima, pure white. Very large. 250

" officinalis alba fl. pl., early white......2 200

" officinalis rubra fl. pl., early crimson....2 00

400

600

600

600

800

600

“ sinensis. Fine assortment of varieties.. 150

\section{LIST OF VARIETIES.}

ALBA PLENA. Sweet white.

DUKE OF WELLINGTON. Yellowish white.

FAUST. Lilac pink.

JEAN D'ARC. White.

MODEST GUERIN. Rosy purple.

NOBILISSIMA. Very fine, large, bright deep pink, silvery border.

ODORATA. Yellowish white.

SAPHO. Dark red. 


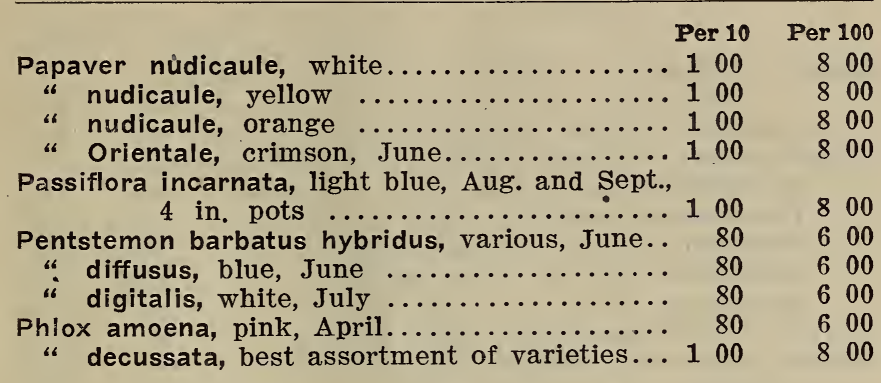

\section{LIST OF PHLOX DECUSSATA.}

AURORA BOREALIS. Orange red, purple centre. CARRAN DE ACHE. Rosy carmine.

COQUELICOT. Fine pure scarlet, with deep carmine eye.

CHAMPS ELYSEES. Rich purplish crimson.

EPOPEE. Violet, bright fiery center.

EUGENE DANZANVILLIERS. Lilac, shading white.

INDEPENDENCE. Large pure white.

LA VAGNE. Beautiful combination of rosy pink and lavender.

L'EVENEMENT. Saimon pink.

L'ESPERANCE. Bright lilac.

MAD. P. LANGIER. Briglit red, vermillion center.

PRINCESS LOUISE. White, small pink eye.

QUEEN. Pure white.

RICHARD WALLACE. White, crimson center.

TERRE NEUVE. Lilac, crimson center.

WILLIAM ROBINSON. Tall, salmon pink.

Phlox subulata rosea, pink, April and May.... 80

“ subulata Sadie, lavender, April and May.. 80

Physostegia denticulata, lilac, July and Aug.... 80

“Virginica, lilac, Aug. and Sept........ 80

“Virginica alba, white, Aug. and Sept..... 100

Plantago maxima, white, July............. 100

Platycodon grandiflora, blue, July to Oct..... 100

" grandiflora album, white, July to Oct... 100

“ Mariesii, blue, dwarf, July to Oct....... 100

Polemonium reptans, blue, May............ 80

“ Richardsoni, blue, May............. 80

Polygonum cuspidatum, white, August, Sept... 80

Primula polyanthus, various, April......... 80

Pyrethrum Balsamita, fragrant foliage........ 80

" roseum, shades of pink and red, May and June ...................... 100

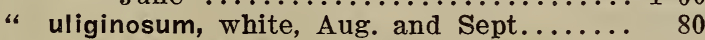

600

$\begin{array}{lll}6 & 00\end{array}$

$\begin{array}{lll}6 & 00\end{array}$

$\begin{array}{lll}6 & 00\end{array}$

800

800

800

800

800

600

$\begin{array}{lll}6 & 00\end{array}$

$\begin{array}{lll}6 & 00\end{array}$

600

600

800

600

Ranunculus acris fl. pl., yellow, May and

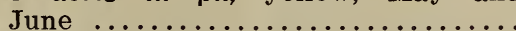

Rudbeckia fulgida, golden yellow, July and Aug.

" laciniata "Golden Glow," yellow, Aug. and

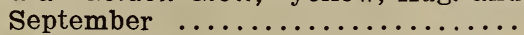

“ Newmanni, golden yellow, July and Aug..

“ sub-tomentosa, golden yellow, July and August ..................... 80

Ruta graveolens, yellow ................. 100

Salvia azurea grandiflora, blue, Aug............ 100

" nutans, blue, June and July............. 100

Sanguinaria canadensis, white, April and May.. 60

Santolina incana

80
600

600

800

800

800

400

600 
Saponaria officinalis, pinkish white, Aug. and

September .................. 80

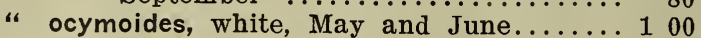

Sedum album, Stonecrop, white, Aug. and Sept. 80

"Kamptschaticum, yellow, July and Sept. . 80

“ Hispanicum, pink, June and July...... 80

" hybridum, yellow, July and Sept......... 80

“ sexangulare, yellow, June and July..... 80

“ spectabilis, pink, Aug. and Sept....... 100

Sisyrinchium Bermudianum, blue, May....... 80

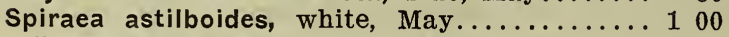

“ filipendula fl. pl. white, May......... 100

“ Japonica, white, May .................. 100

“ lobata-venusta, pink, June ............. 100

“ multiflora compacta, white, May and June. 100

“ palmatum, pink, June ............... 100

“ ulmaria alba plena, double white, June and July .................. 80

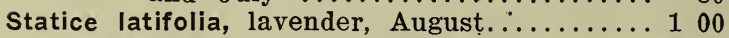

“ Gmelini, lavender, August.......... 100

Stokesia cyanea, blue, July to Sept........ 80

Thalictrum adiantifolium, handsome foliage.... 100

“ aquilegifolium roseum, pink, June....... 100

" glaucum, handsome foliage .......... 100

Thermopsis Caroliniana, yellow, June...... 100

Thymus Serpyllum, pink, May and June..... 80

"Serpyllum splendens, pink, May and June. $\quad 80$

“ Serpyllum variegata, golden variegata... 80

“ vulgaris, pink ................. 80

Tradescantia Virginica, blue, May to July.... 80

" Virginica alba, white, May, July...... 80

“Virginica purpureum, purple, May to July. 100

Tritoma uvaria Express, coral and yellow,

August .................. 125

“ uvaria grandiflora, red and yellow, Aug.. 100

“ uvaria Pfitzeri, coral, July to Oct........ 100

“ uvaria Tuckii, brown red, June to Aug.. 125

Valeriana officinalis, pinkish, May ind June.... 100

Vernonia Jamesii, purple, Aug. and Sept..... 100

Veronica candida, silvery foliage, blue flowers, June and July ............... 80

“ circaeoides, blue, June ............... 80

“ Hendersoni (longifolia subsessilis), blue,

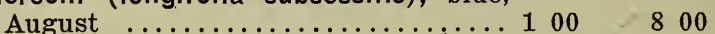

“Montana, blue, June and July............ 80

“ teucrium, blue, June............... 80

Viola, "Californian" ...................... 100

" odorata Blue, "Sweet Violet," April and

May ...................... $100 \quad 800$

" odorata White, "Sweet Violet," April and

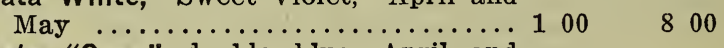

" odorata "Czar," double blue, April and

May ....................... $100 \quad 800$

\section{HARDY FERNS}

Aspidium acrostichoides, "Christmas Fern" ... 80

" cristatum, "Crested Shield Fern"....... 80

“ marginale, "Marginal Fern" ........... 80

" spinulosum ........................ 80

"Thelyptera, "Lady Fern" ............ 80

600

800

600

600

600

600

$6 \cdot 00$

800

600

800

800

800

800

800

800

600

800

800

600

800

800

800

800

$\begin{array}{ll}6 & 00\end{array}$

$\begin{array}{ll}6 & 00\end{array}$

600

600

$\begin{array}{ll}6 & 00\end{array}$

$\begin{array}{lll}6 & 00\end{array}$

800

1000

800

800

1000

800

800

600

600

$\begin{array}{ll}6 & 00\end{array}$

800 
Asplenium angustifolium, "Narrow-leaved

Per 10 Per 100 Spleenwort" ............... 80

Onoclea sensibilis, "Sensitive Fern"......... 80

"Struthiopeteris, "Ostrich Fern" ........... 80

Osmunda cinnamomea, "Cinnamon Fern".... 100

"Claytoniana, "Flowering Fern" ........ 100

" regalis, "King Fern" ............. 150

Polypodium hexagonopterum ........... 60

"vulgare, "Rock Polypod" ................ 60

Pteris aquilina, Brake or Braken.......... 60

\section{HARDY GRASSES}

Arundo donax, Giant Reed .............2 50

Bambusa Metake, Evergreen Bamboo......... 250

Calamagrostis stricta variegata .......... 80

Eulalia Japonica, False Pampas Grass....... 200

“ Japonica gracillima ..............2 00

" Japonica variegata, green and white striped ....................2. 00

"Japonica Zebrina, green barred with bronze, yellow ............2 00

Uniola latifolia, a pretty grass with plumes, useful for vases ............ 100 


\section{MEEHANS'}

\section{MALLOW MARVELS}

RICH, GORGEOUS, HARDY

PERENNIAL CREATION

\section{JCost Brilliant New Production of Scientific Plant Breeding}

BLAZE with their immense, brilliant flowers, our
field of Mallow Marvels, when in flower, was a
sight to behold. Immense flowers from eight to ten inches in diameter, in fiery crimson, rich blood-red, soft shell-pink and clear snowy white. Their great beauty is indescribable. It seems impossible to reproduce the glorious colors of the flowers and the illustration on the front cover conveys a very poor idea of their actual beauty. They must be seen to be fully appreciated.

Visitors to our nurseries are amazed at the wonderful show. Meehans' Mallow Marvels surpass all other perennials in profuseness of bloom, flowering propensities and brilliancy of color. From late July until October frosts arrive, the flowers continue to appear in profusion.

A hybrid of our own production and brought up to its present point of form, color and beauty by careful seed selection, covering a period of several years.

Absolutely hardy, the Mallow Marvels have been tested and are thriving in Canada and in the mountain portions of the Northern States, as successfully as in Georgia and Florida. Of herbaceous character. They come up year after year and thrive under varied conditions.

\section{Prices for Strong Two-Year-0ld Roots}

Crimson Marvel (shades of Crimson) .

Red Marvel (shades of Red)

White Marvel

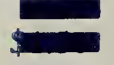

